\title{
Hydrogeologic Framework for Characterization and Occurrence of Confined and Unconfined Aquifers in Quaternary Sediments in the Glaciated Conterminous United States-A Digital Map Compilation and Database
}

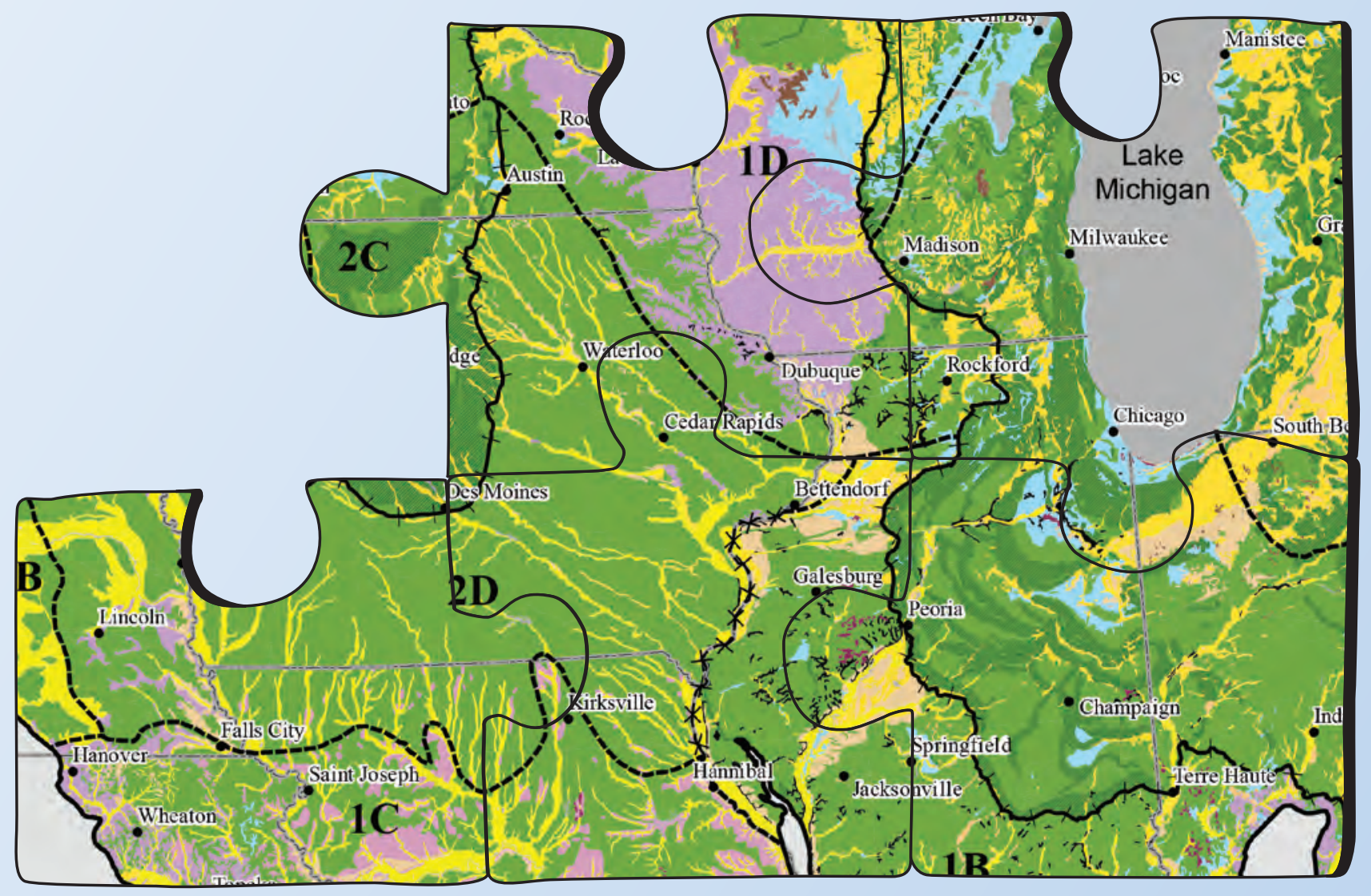

Data Series 1090 
Cover. Puzzle pieces showing hydrogeologic terranes of the northern Midwest part of the map of the contiguous United States; from figure 2 of this report. 


\section{Hydrogeologic Framework for Characterization and Occurrence of Confined and Unconfined Aquifers in Quaternary Sediments in the Glaciated Conterminous United States-A Digital Map Compilation and Database}

By Adel E. Haj, David R. Soller, James E. Reddy, Leon J. Kauffman, Richard M. Yager, and Cheryl A. Buchwald

Data Series 1090 


\title{
U.S. Department of the Interior \\ RYAN K. ZINKE, Secretary
}

\author{
U.S. Geological Survey \\ James F. Reilly II, Director
}

U.S. Geological Survey, Reston, Virginia: 2018

For more information on the USGS - the Federal source for science about the Earth, its natural and living resources, natural hazards, and the environment-visit https://www.usgs.gov or call 1-888-ASK-USGS.

For an overview of USGS information products, including maps, imagery, and publications,

visit https://store.usgs.gov.

Any use of trade, firm, or product names is for descriptive purposes only and does not imply endorsement by the U.S. Government.

Although this information product, for the most part, is in the public domain, it also may contain copyrighted materials as noted in the text. Permission to reproduce copyrighted items must be secured from the copyright owner.

\footnotetext{
Suggested citation:

Haj, A.E., Soller, D.R., Reddy, J.E., Kauffman, L.J., Yager, R.M., and Buchwald, C.A., 2018, Hydrogeologic framework for characterization and occurrence of confined and unconfined aquifers in quaternary sediments in the glaciated conterminous United States—A digital map compilation and database: U.S. Geological Survey Data Series 1090, 31 p., https://doi.org/10.3133/ds1090.
}

ISSN 2327-638X (online) 


\section{Contents}

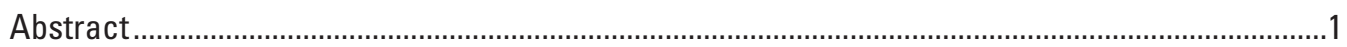

Introduction

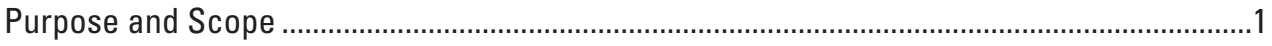

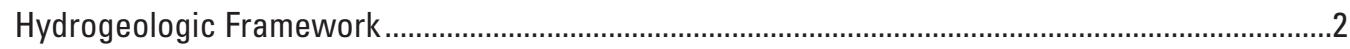

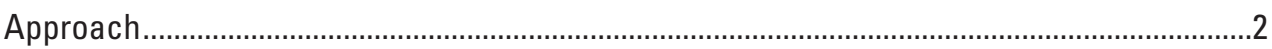

The Glacial Environments and Surficial Sediments Geodatabase ..........................................2

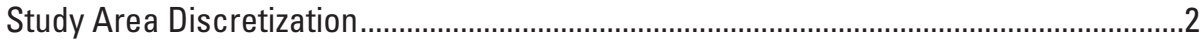

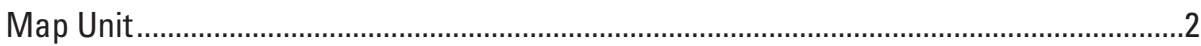

Geomorphic Modifier ...................................................................................................

Stratified Compared to Unstratified Sediments ................................................................

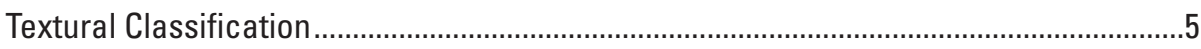

Bedrock Lithology and Coarse-Grained, Stratified Sediments ..........................................5

Interpretations and Applications ....................................................................................

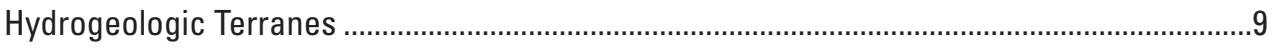

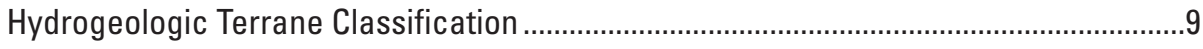

Hydrogeologic Terrane Description..........................................................................

Hydrogeologic Terranes of Lower Complexity........................................................10

Terrane 1A—Predominantly Late Wisconsinan Sediments in

Eastern Ohio Through New England ................................................10

Terrane 1B-Generally Pre-Late Wisconsinan Sediments in

Southern Ohio, Indiana, and Illinois .................................................10

Terrane 1C-Older, Partially Eroded Glacial Sediments in

Central Missouri ..............................................................................11

Terrane 1D-Older, Partially Eroded Glacial Sediments Around the Driftless Area ...................................................................................11

Terrane 1E-Late Wisconsinan Sediments Near Lakes Superior and

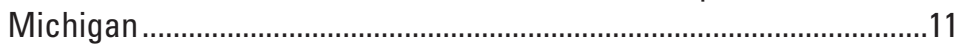

Terrane 1F-Thin Late Wisconsinan Sediments in Montana and North Dakota ....................................................................................11

Terrane 1G-Residual Soils and Sediments From the Cordilleran

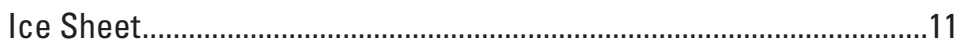

Hydrogeologic Terranes of Moderate Complexity ................................................11

Terrane 2A-Predominantly Late Wisconsinan Sediments, Notably With Buried Valley Systems .............................................................11

Terrane 2B — Late Wisconsinan Sediments From Lake Superior Lobe ..........12

Terrane 2C-Late Wisconsinan Sediments in the Des Moines Lobe .............12

Terrane 2D—Older Sediments in lowa and Kansas ........................................12

Terrane 2E_-Late Wisconsinan Sediments in the Dakotas..............................12

Hydrogeologic Terranes of Higher Complexity .......................................................12

Terrane 3A-Interlobate Area in Southern Michigan Between Lake Michigan, Saginaw, and Lake Huron-Erie Lobes...............................12

Terrane 3B-Interlobate Area in Minnesota Between Labrador and Keewatin Laurentide Centers.............................................................13

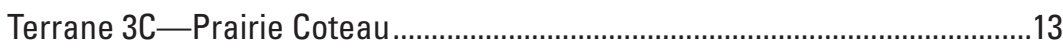


Hydrogeologic Terranes with Thick, Coarse-Grained, Stratified

Quaternary Sediments

Terrane 4A—Long Island and Cape Cod.......................................................13

Terrane 4B-Eastern Nebraska ...................................................................13

Interpretive and Application Limitations......................................................................14

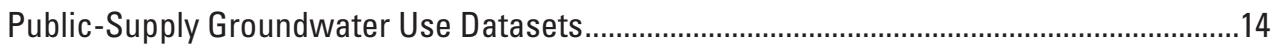

Lithologic Database Derivatives ......................................................................................17

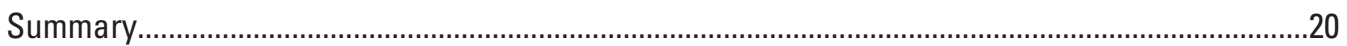

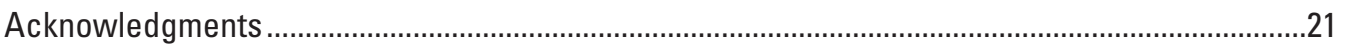

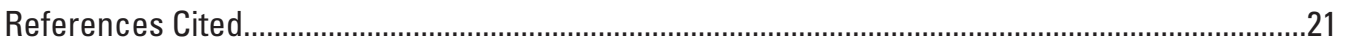

\section{Figures}

1. Map showing distribution of source data from the Quaternary Atlas and Surficial Materials Map coverages used for the Glacial Environment and Surficial Sediments geodatabase for the glaciated conterminous United States ............1

2. Map showing Glacial Environment and Surficial Sediments geodatabase map units in the glaciated conterminous United States.

3. Map showing textural classification of Glacial Environment and Surficial Sediments geodatabase map units in the glaciated conterminous United States.

4. Map showing generalized bedrock lithology and overlying Glacial Environment and Surficial Sediments geodatabase coarse-grained, stratified sediments in the glaciated conterminous United States.

5. Map showing comparison of extent of coarse-stratified sediment from Kontis and others (2004) and the Glacial Environment and Surficial Sediments geodatabase, southeastern Vermont

6. Map showing comparison of extent of coarse-stratified sediment from Kontis and others (2004) and the Glacial Environment and Surficial Sediments geodatabase, central Maine.

7. Map showing comparison of extent of coarse-stratified sediment from Kontis and others (2004) and the Glacial Environment and Surficial Sediments geodatabase, southern Vermont and New Hampshire

8. Map showing hydrogeologic terranes and the thickness and character of glacial sediments in the glaciated conterminous United States

9. Map showing hydrogeologic terranes and the maximum glacial advance of the glaciated conterminous United States.

10. Maps showing glacial features, by hydrogeologic terrane, in the glaciated conterminous United States

11. Graph showing comparison of public-supply groundwater withdrawals in the glaciated conterminous United States estimated by this study and by Maupin and others (2014)

12. Map showing density of lithologic logs aggregated on a 5-kilometer grid in the glaciated conterminous United States. 


\section{Tables}

1. Classification of map units in the Glacial Environment and Surficial Sediments geodatabase classification and corresponding map unit values from the Quaternary Atlas and the Surficial Materials Map....

2. Subcategories for map units for Quaternary sediments in the Glacial Environment and Surficial Sediments geodatabase.

3. Textural classification from the Glacial Environment and Surficial Sediments geodatabase (this report) compared with textural descriptions of sediments from the Quaternary Atlas and the Surficial Materials Map.

4. Groundwater usage for public-supply water systems, by State, in the glaciated

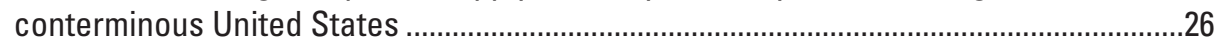

5. Fields included in system-level and source-level water-use tables...............................15

6. Characteristics of sediment and aquifer-material intervals obtained from lithologic logs

\section{Conversion Factors}

International System of Units to U.S. customary units

\begin{tabular}{lll}
\hline \multicolumn{1}{c}{ Multiply } & By & \multicolumn{1}{c}{ To obtain } \\
\hline meter $(\mathrm{m})$ & Length & \\
kilometer $(\mathrm{km})$ & 3.281 & foot $(\mathrm{ft})$ \\
kilometer $(\mathrm{km})$ & 0.6214 & mile $(\mathrm{mi})$ \\
meter $(\mathrm{m})$ & 0.5400 & mile, nautical $(\mathrm{nmi})$ \\
\hline & 1.094 & yard $(\mathrm{yd})$ \\
\hline square kilometer $\left(\mathrm{km}^{2}\right)$ & Area & \\
square kilometer $\left(\mathrm{km}^{2}\right)$ & 247.1 & acre \\
\hline & 0.3861 & square mile $\left(\mathrm{mi}^{2}\right)$ \\
\hline cubic meter per year $\left(\mathrm{m}^{3} / \mathrm{yr}\right)$ & Flow rate & \\
cubic meter per day $\left(\mathrm{m}^{3} / \mathrm{d}\right)$ & 811.03 & acre-foot per year $(\mathrm{acre}-\mathrm{ft} / \mathrm{yr})$ \\
\hline
\end{tabular}

\section{Datum}

Vertical coordinate information is referenced to the North American Vertical Datum of 1988 (NAVD 88).

Horizontal coordinate information is referenced to the North American Datum of 1983 (NAD 83).

Elevation, as used in this report, refers to distance above the vertical datum. 


\section{Supplemental Information}

Per capita water use is given in cubic meters per person per day $\left(\mathrm{m}^{3} \mathrm{ppd}\right)$.

Geologic time is given in years before present (yBP).

\section{Abbreviations}

$\begin{array}{ll}\text { AWUDS } & \text { Aggregate Water-Use Data System } \\ \text { GESS } & \text { Glacial Environments and Surficial Sediments [geodatabase] } \\ \text { NAWQA } & \text { National Water Quality Assessment } \\ \text { PWS } & \text { public water system } \\ \text { SDWIS } & \text { Safe Drinking Water Information System } \\ \text { USGS } & \text { U.S. Geological Survey }\end{array}$




\title{
Hydrogeologic Framework for Characterization and Occurrence of Confined and Unconfined Aquifers in Quaternary Sediments in the Glaciated Conterminous United States-A Digital Map Compilation and Database
}

\author{
By Adel E. Haj, David R. Soller, James E. Reddy, Leon J. Kauffman, Richard M. Yager, and Cheryl A. Buchwald
}

\begin{abstract}
The U.S. Geological Survey has created a hydrogeologic framework for Quaternary sediments in glaciated areas of the conterminous United States that categorizes, maps, and characterizes the glacial sediments at and beneath the land surface. The hydrogeologic framework divides the glaciated United States into 17 distinct hydrogeologic terranes using a geologic approach based on previous mapping, and was characterized using the Glacial Environments and Surficial Sediments geodatabase compiled from the Quaternary Atlas of the United States map series, the Surficial Materials Map of the United States, and several Integrated Geologic Map Databases for the United States; a groundwater use database compiled from public-supply, water-well data; and a lithologic database compiled from State-managed well records and geologic logs. This framework is to be used to assess the occurrence and characteristics of confined and unconfined glacial aquifers, their distribution and extent, and their potential intrinsic susceptibility and vulnerability.
\end{abstract}

\section{Introduction}

The U.S. Geological Survey (USGS) has completed a study to assess the occurrence and characteristics of confined and unconfined glacial aquifers in the conterminous United States, which serves as a public water supply for about 43 million people; about 60 percent of the groundwater is derived from Quaternary sediments (Yager and others, 2018b). In 2012, the USGS National Water Quality Assessment (NAWQA) program began the third decade of tracking water quality in the United States. Within the NAWQA program's scope of work is an assessment of the quality and vulnerability of groundwater in 20 principal aquifer systems that provide 75 percent of the Nation's drinking water (Rowe and others, 2013). The glacial aquifer system, defined herein as the collection of aquifers within Quaternary sediments in the glaciated conterminous United States (fig. 1), is included as one of these principal aquifers because groundwater withdrawals from this system account for about 25 percent of the Nation's drinking water.

Figure 1. Distribution of source data from the Quaternary Atlas (Fullerton and Richmond, variously dated) and Surficial Materials Map (Soller and others, 2009) coverages used for the Glacial Environment and Surficial Sediments geodatabase for the glaciated conterminous United States. Map is available at https://doi.org/10.3133/ds1090.

Continuous spatial datasets with consistent description of the entire glaciated conterminous United States did not previously exist; therefore, the USGS studied and organized multiple hydrogeologic and geospatial datasets into a hydrogeologic framework for the glacial aquifer system. Maps and geospatial datasets were prepared that three dimensionally characterize the Quaternary sediments of the glaciated conterminous United States, more specifically defined as Quaternary sediment north of the line of maximum glacial advance (Booth, 2003; Soller and others, 2012). These data were intended to aid in the identification and explanation of regional patterns in aquifer occurrence, productivity, and water quality in the glacial aquifer system.

\section{Purpose and Scope}

This report describes the components of the hydrogeologic framework: the Glacial Environments and Surficial Sediments (GESS) geodatabase, which includes lithologic, geomorphic, and stratigraphic characterization of surficial and glacial sediments; hydrogeologic terranes; public-supply and domestic well databases containing groundwater use information; and a geospatial framework for visualizing and interpreting available subsurface lithologic information derived from State-managed well records and geologic logs.

Not all sediments in the study area are glacial in origin or association. For example, residual soil, bedrock outcroppings, 
colluvial sediment, and mass wasting sediments are present in the study area near the limits of glaciation and where glacial sediments were eroded or not deposited. The study area also is dissected by stream valleys underlain by alluvial sediment or overlain by eolian sediment (sand and loess). In some of these cases, sediments are not associated with glaciation; moreover, sediments may not be Quaternary in age, but may be important hydrologically, and so were included in the scope of this report.

\section{Hydrogeologic Framework}

Multiple hydrogeologic and geospatial datasets were organized into the hydrogeologic framework for the glacial aquifer system. The components of the hydrogeologic framework are described in this section, including the GESS geodatabase, hydrogeologic terranes, public-supply and domestic well databases containing groundwater use information; and well log database derivatives of the geospatial framework for visualizing and interpreting available subsurface lithologic information derived from State-managed well records and geologic logs.

\section{Approach}

Surficial and bedrock geologies, to a large extent, control the occurrence and geometry of aquifers and the likelihood that they might provide a useable supply of groundwater. Predictability of geology is especially difficult for terrestrial depositional settings such as glaciated areas, given the nature of glaciofluvial processes and the numerous glaciations to which large areas of the United States have been subjected. At the land surface these sediments may be well understood and mapped but, in the subsurface, they generally are poorly understood, at least to the level of detail sufficient to delineate individual aquifers. The reasons for this include the high cost of obtaining subsurface information and difficulties in predicting the geometry and variations in lithology of buried aquifers. The scale at which the hydrogeology can be characterized is limited by the scale at which geologic sediments have been mapped. This study has adopted a generalized approach to characterizing and classifying the glacial geologic framework of the United States, taking into account the regional character of surficial and bedrock geology, to provide a tool for describing the Nation's aquifers within the glacial aquifer system, and the potential vulnerability to contamination of these aquifers at depth.

\section{The Glacial Environments and Surficial Sediments Geodatabase}

Two previous studies that produced maps and geodatabases characterizing surficial sediments at the national scale were used to create the GESS geodatabase, a geospatial database that categorizes, maps, and characterizes the physical properties of the glacial sediments. The first and primary source was the Quaternary Atlas of the United States map series (Fullerton and Richmond, variously dated). Geodatabases from Fullerton and Richmond (variously dated), a 1:1,000,000-scale $4^{\circ} \times 6^{\circ}$ quadrangle map series, were downloaded and merged into a single geodatabase (referred to herein as the "Quaternary Atlas") for the glaciated conterminous United States. The selected quadrangle maps used to create the Quaternary Atlas and the coverage extent of the study area are shown in figure 1. The 1:5,000,000-scale "Map Database for Surficial Materials in the Conterminous United States" (Soller and others, 2009; referred to herein as the "Surficial Materials Map") was used as a secondary data source, filling in the gap in the Quaternary Atlas coverage in the northwestern United States (fig. 1).

Although the Quaternary Atlas lacked full coverage of the study area, it was selected as the cornerstone for the GESS geodatabase because of the higher resolution (1:1,000,000-scale compared with the Surficial Materials Map database at 1:5,000,000-scale). The Quaternary Atlas also had more mapped spatial elements (that is, polygons), about 800,000 (compared with the Surficial Materials Map, which had 9,555 spatial elements) with detailed sedimentological, geomorphological, and geological attributes derived from State and Canadian Provincial geological surveys, universities, the Geological Survey of Canada, the USGS, and private industry. Although the Surficial Materials Map was not primarily used to derive new GESS geodatabase attributes in the Quaternary Atlas coverage area, it is a geodatabase with consistent and verified descriptions and extents of surficial sediments in the study area; therefore, all its spatial elements and attributes were retained in the GESS geodatabase for reference and comparison purposes.

\section{Study Area Discretization}

The study area was discretized for the GESS geodatabase using spatial elements from the Quaternary Atlas, modified slightly to fill gaps at quadrangle boundaries and extended inlets along the eastern U.S. coastline. Where the Quaternary Atlas lacked coverage in the northwest, spatial elements from the Surficial Materials Map were used. New attributes for the combined framework were derived for this study from the Quaternary Atlas and the Surficial Materials Map maps and databases that describe aspects of the depositional environment, texture and character, and geomorphic expression of the surficial sediments and may affect the hydrogeologic properties of the sediments. These GESS geodatabase attributes are described below.

\section{Map Unit}

The GESS geodatabase map unit (attribute GESS MU) values were designated using Quaternary Atlas map unit descriptions (attribute N_MAPUNITS) and geologic 
description codes (or geocodes; attribute GEOCODE; Fullerton and Richmond, variously dated); terminology and geocode abbreviations were defined by Fullerton and others (2003). The Quaternary Atlas map series is the culmination of the efforts of numerous scientists over decades, and thus contained inconsistencies in use of terminology, outdated terms, incomplete descriptions, or a combination of these inconsistencies. Fullerton and others (2003) standardized the terminology used for each Quaternary Atlas quadrangle map, but some variability still exists. Variability and inconsistencies in lithologic descriptive terminology also exists among the quadrangles maps. For assignment of GESS_MU attribute values, identical Quaternary Atlas map unit descriptions were grouped, and then those groups were combined into categories based upon similarity in map unit descriptions and using the classification system of Fullerton and others (2003). The resultant 14 Quaternary Atlas map unit categories were translated to GESS geodatabase map unit values: alluvial sediment, bedrock, colluvial sediment, eolian sediment, fill, ice-contact sediment, lacustrine sediment, marine sediment, organic sediment, outwash sediment, residual soil, solifluction sediment, till, and water (table 1). Where insufficient information in the lithologic description was present in the Quaternary Atlas map unit attribute, the geocode attribute was used to set the value for the GESS geodatabase map unit such that every spatial element in the GESS geodatabase possessed a map unit value. In the part of the study area with no coverage in the Quaternary Atlas, unit names for the spatial elements from the Surficial Materials Map were correlated to the 14 GESS geodatabase map unit values (table 1).

Table 1. Classification of map units in the Glacial Environment and Surficial Sediments geodatabase classification and corresponding map unit values from the Quaternary Atlas and the Surficial Materials Map.

[The Quaternary Atlas is from Fullerton and Richmond (variously dated); the Surficial Materials Map is from Soller and others (2009). GESS_MU, map unit attribute in the Glacial Environment and Surficial Sediments (GESS) geodatabase; N_MAPUNITS, Quaternary Atlas map unit attribute; GEOCODE, Quaternary Atlas attribute for geological classification; NA, not applicable]

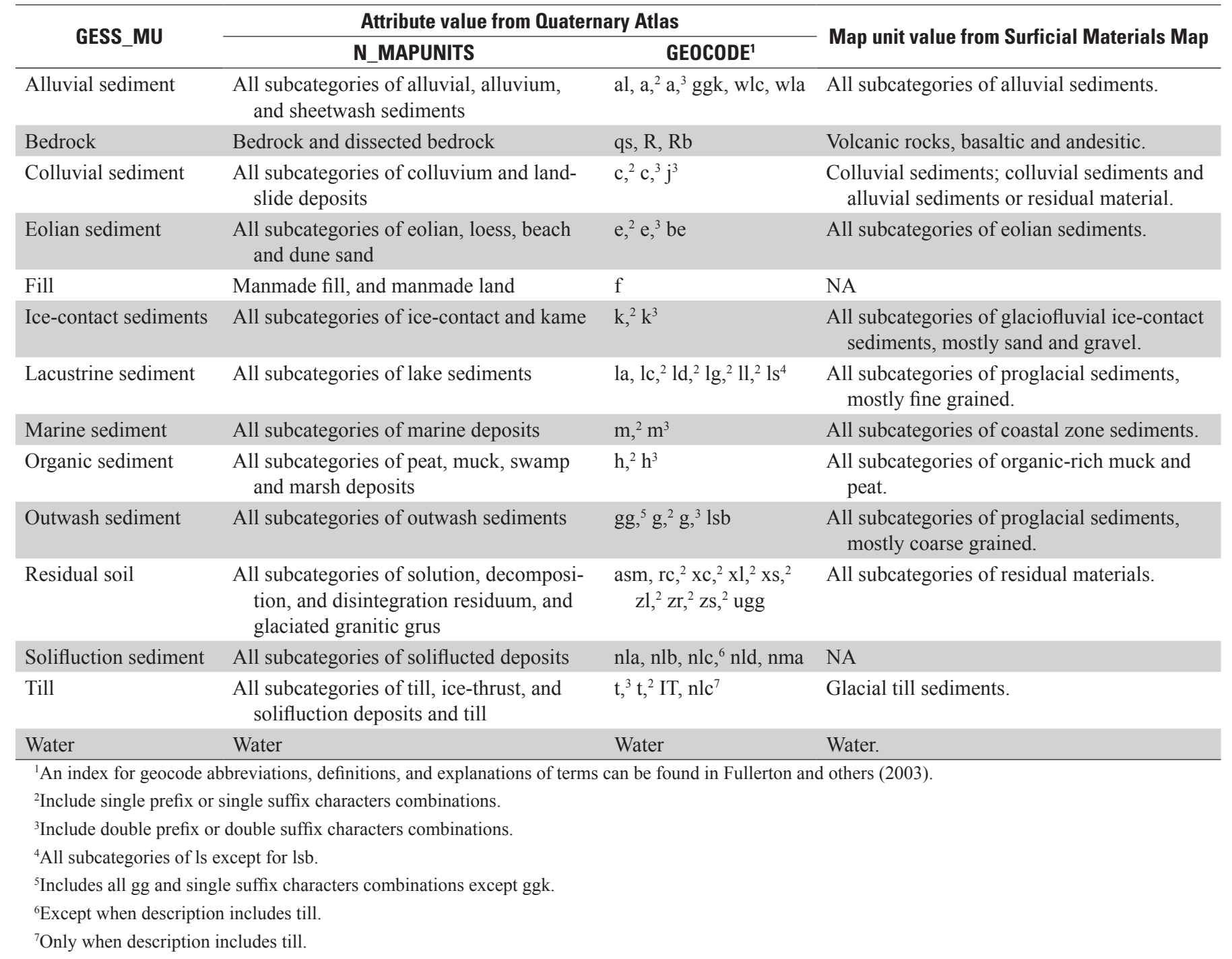


Not all GESS geodatabase map units represent Quaternary sediments of glacial origin. Colluvial sediment, residual soil, and solifluction sediment GESS geodatabase map units are generally areas with thin or no glacial sediment, where sediment tends to be of greater geologic age, or is present on upland or steeply sloped surfaces. In all these cases, the likelihood of a glacial aquifer existing in these areas is very low and, therefore, fall outside the scope of this study. For similar reasons, bedrock, fill, and water GESS geodatabase map units also were disregarded, leaving the focus of this study on areas with the remaining eight GESS geodatabase map unit values: alluvial sediment, eolian sediment, ice-contact sediment, lacustrine sediment, marine sediment, organic sediment, outwash sediment, and till (fig. 2; table 2).

Figure 2. Glacial Environment and Surficial Sediments (GESS) geodatabase map units (GESS_MU attribute) in the glaciated conterminous United States. Map is available at

https://doi.org/10.3133/ds1090.

\section{Geomorphic Modifier}

The hydrogeologic properties of many glacial sediments may be affected by their geomorphology and depositional environment. This is particularly true for glacial till. As a result, the attribute "GESS_Modifier" was created for each spatial element and given a value of " $\mathrm{e}$ " (end moraine), "g" (ground moraine), "s" (stagnation moraine), "d" (discontinuous or attenuated), or " $\mathrm{f}$ " (solifluction sediment) primarily for those spatial elements with GESS geodatabase map unit values of "till" (table 2). All GESS_Modifier values for those units were set to "g," unless information was present in the lithologic descriptions, geocodes, or other attributes in the Quaternary Atlas and the Surficial Materials Map to assign an alternative value. Other spatial elements may have GESS Modifier values because of potential importance in future hydrogeologic applications of this database (table 2).

\section{Stratified Compared to Unstratified Sediments}

The StratSed attribute was created to identify the extent of sediments that have been transported by wind or water before deposition; these sediments were considered "stratified." Aquifers are typically composed of coarse-grained, stratified glacial sediments, such as kame sands, outwash gravels, or eolian sand, whereas the unstratified sediments, primarily till, generally are less productive or are confining units. All spatial elements with GESS_MU values of alluvial sediment, eolian sediment, ice-contact sediment, lacustrine sediment, marine sediment, and outwash sediment were identified as stratified sediments, and the StratSed attribute value was set to "1;" the remaining spatial elements with a GESS_MU attribute value of organic sediment (including precluded GESS geodatabase map units residual soil and solifluction sediment) and till were classified as unstratified, and the StratSed attribute value was set to " 0 " (table 2 ).

Table 2. Subcategories for map units for Quaternary sediments in the Glacial Environment and Surficial Sediments geodatabase.

[GESS, Glacial Environment and Surficial Sediments geodatabase; GESS_MU, GESS map unit attribute; StratSed, GESS attribute for stratified sediment; CrseStratSed, GESS attribute for coarse, stratified sediments; Texture6, GESS attribute that classifies texture; GESS_Modifier, GESS attribute imparting additional details for the spatial element; NA, no data available; d, discontinuous; e, end moraine; f, solifluction sediment; g, ground moraine; s, stagnation moraine]

\begin{tabular}{|c|c|c|c|c|}
\hline GESS_MU & StratSed ${ }^{1}$ & CrseStratSed $^{2}$ & Texture6 & GESS_Modifier \\
\hline \multirow[t]{2}{*}{ Alluvial } & \multirow[t]{2}{*}{1} & 1 & Mostly sandy and sandy-silty & \multirow[t]{2}{*}{ NA } \\
\hline & & 0 & Mostly silty $^{3}$ and silty-clayey ${ }^{3}$ & \\
\hline \multirow[t]{2}{*}{ Eolian } & \multirow[t]{2}{*}{1} & 1 & Mostly sandy & \multirow[t]{2}{*}{ NA } \\
\hline & & 0 & Sandy-silty & \\
\hline Ice-contact & 1 & 1 & Mostly sandy & NA \\
\hline \multirow[t]{2}{*}{ Lacustrine } & \multirow[t]{2}{*}{1} & 1 & Mostly sandy ${ }^{3}$ and sandy-silty ${ }^{3}$ & \multirow[t]{2}{*}{ NA, d } \\
\hline & & 0 & Silty-clayey and mostly clayey & \\
\hline \multirow[t]{2}{*}{ Marine } & \multirow[t]{2}{*}{1} & 1 & Mostly sandy & \multirow[t]{2}{*}{ NA, d } \\
\hline & & 0 & Silty-clayey & \\
\hline Organic & 0 & 0 & Mostly organic & NA \\
\hline Outwash & 1 & 1 & Mostly sandy & NA \\
\hline Till & 0 & 0 & Mostly sandy, sandy-silty, mostly silty, silty-clayey, and mostly clayey & $\mathrm{d}, \mathrm{e}, \mathrm{f}, \mathrm{g}, \mathrm{s}$ \\
\hline
\end{tabular}

${ }^{1} \mathrm{~A}$ value of 1 indicates stratified, and 0 indicates unstratified sediments.

${ }^{2} \mathrm{~A}$ value of 1 indicates coarse, stratified sediments, and 0 indicates unstratified sediments or fine, stratified sediments.

${ }^{3}$ Few spatial elements with this value and associated GESS_MU. 


\section{Textural Classification}

A six-bin classification system for sediment texture was created for all the spatial elements of the GESS geodatabase, attribute "Texture6." The Quaternary Atlas textural descriptions were grouped, simplified, and categorized into six categories: mostly sandy, sandy-silty, mostly silty, silty-clayey, mostly clayey, and mostly organic. This classification scheme allowed for investigation of the potential hydrogeologic effects of sediment texture in the Quaternary Atlas while remaining compatible with the more generalized, four-bin textural classification system used by the Surficial Materials Map (table 3). Although the terminology and the generalizing of textural attributes used in the Surficial Materials Map is similar to the terminology and generalization in the GESS geodatabase, it should be noted that some discrepancies may exist between the Quaternary Atlas descriptions, the Surficial Materials Map textural classes, and textural values in the GESS geodatabase. An example of this can be seen in table 3, where the GESS geodatabase Texture6 value "mostly silty" derived from Surficial Materials Map spatial elements would be correlative with spatial elements derived from the Quaternary Atlas with "sandy-silty," "mostly silty," and "silty-clayey" values. The values are intended to be qualitative descriptions of relative sediment textures for till (unstratified) and stratified sediments independently; for example, "mostly sandy" till is coarser in texture than "silty-clayey" till but would not have the same particle-size distribution as "mostly sandy" outwash sediment. The extent of the GESS geodatabase textural classes are displayed in figure 3 .

Figure 3. Textural classification of Glacial Environment and Surficial Sediments geodatabase map units in the glaciated conterminous United States. Map is available at https://doi.org/10.3133/ds1090.

\section{Bedrock Lithology and Coarse-Grained, Stratified Sediments}

Groundwater interaction between aquifers in glacial sediments and the underlying bedrock may have important implications when comparing water-quality data from the glacial aquifer system in a hydrogeologic framework; for example, groundwater exchange with carbonate bedrock aquifers may affect the buffering capacity of the overlying glacial aquifers. To better anticipate where these interactions might be present and potentially affect water quality, a bedrock geology map was overlain by GESS geodatabase spatial elements possessing coarse, stratified glacial sediments. The GESS geodatabase attribute for coarse, stratified sediments (attribute CrseStratSed) was created and assigned a value of " 1 " for spatial elements with a StratSed attribute value of "1" and Texture6

Table 3. Textural classification from the Glacial Environment and Surficial Sediments geodatabase (this report) compared with textural descriptions of sediments from the Quaternary Atlas and the Surficial Materials Map.

[Glacial Environment and Surficial Sediments (GESS) geodatabase is from this report; the Quaternary Atlas is from Fullerton and Richmond (variously dated); and the Surficial Materials Map is from Soller and others (2009). Texture6, GESS attribute that classifies texture in one of six values; Texture4, GESS attribute that classifies texture in one of four values; GESS_MU, GESS map unit attribute; GEOCODE, Quaternary Atlas attribute for geological classification]

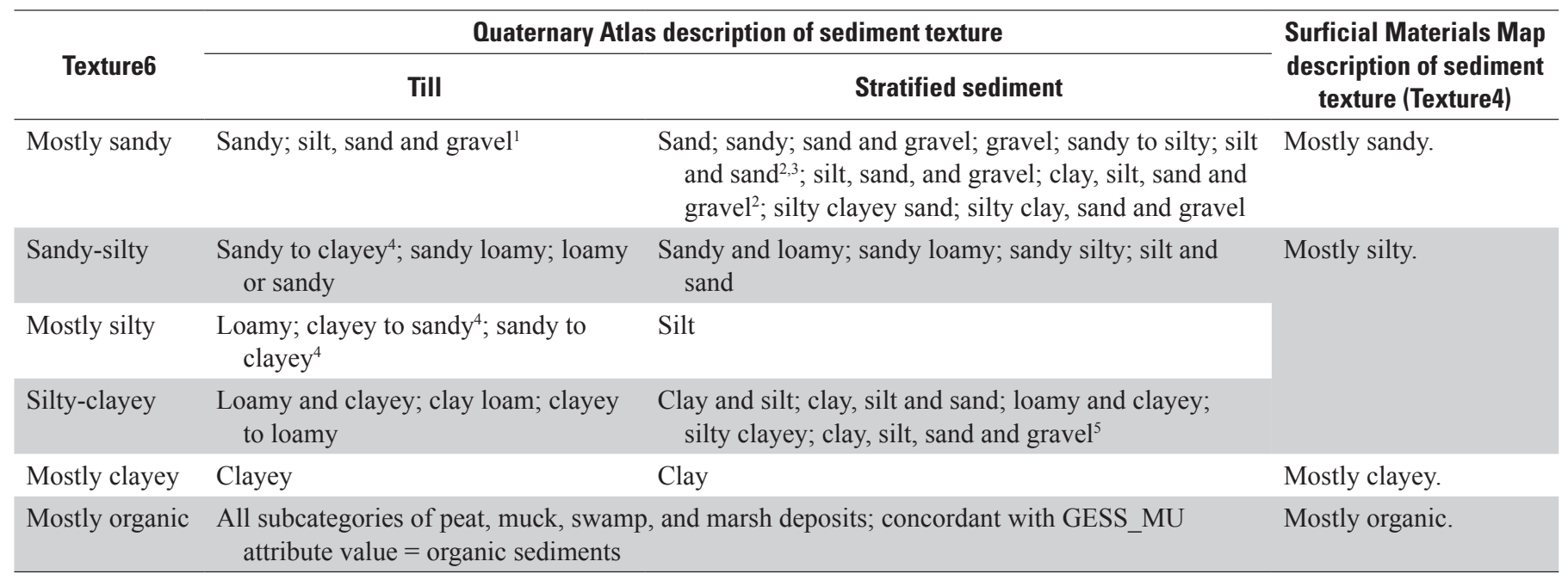

${ }^{1}$ Applies to spatial elements described as ice thrust deposits.

${ }^{2}$ Applies to spatial elements with GESS_MU value of alluvial only.

${ }^{3}$ Applies to spatial elements with GESS_MU value of eolian only.

${ }^{4}$ Variable texture in description, further information gathered from GEOCODE to determine Texture6 value.

${ }^{5}$ Applies to spatial elements with GESS_MU value of lacustrine only. 
attribute value of "mostly sandy" and "sandy silty" (table 2; fig. 4).

Figure 4. Generalized bedrock lithology (modified from the Integrated Geologic Map Databases for the United States) and overlying Glacial Environment and Surficial Sediments geodatabase coarse-grained, stratified sediments in the glaciated conterminous United States. Map is available at https://doi.org/10.3133/ds1090.

The bedrock geology for the GESS geodatabase is an amalgamation of several "Integrated Geologic Map Databases for the United States" (Dicken and others, 2005; Ludington and others, 2007; Nicholson and others, 2007a-c; Stoeser and others, 2007). Using the LITH62 and LITH62MINO attribute values from that integrated geologic map databases and the associated lithclass 6.2 code text descriptions, spatial elements of the integrated geologic map databases were grouped and compared to GESS geodatabase spatial elements. A new GESS geodatabase attribute was created, named "Litho_class," and each GESS geodatabase spatial element and given a Litho_class value of noncarbonate sedimentary rock, carbonate rock, noncarbonate metamorphic rock, volcanic rock, plutonic rock, or undetermined (areas where bedrock lithology was not mapped in the integrated geologic map databases).

Some Litho_class values were further modified from the above classification scheme. Areas described as "mélange" were assigned Litho_class attribute values of "noncarbonate metamorphic rock;" " those described as "dams" were assigned values of "unconsolidated;" and those described as "RI (Rhode Island) coastals" were assigned a value of "plutonic." In the Midwestern United States, some areas classified as unconsolidated materials (LITH62 values) when cross-referenced with

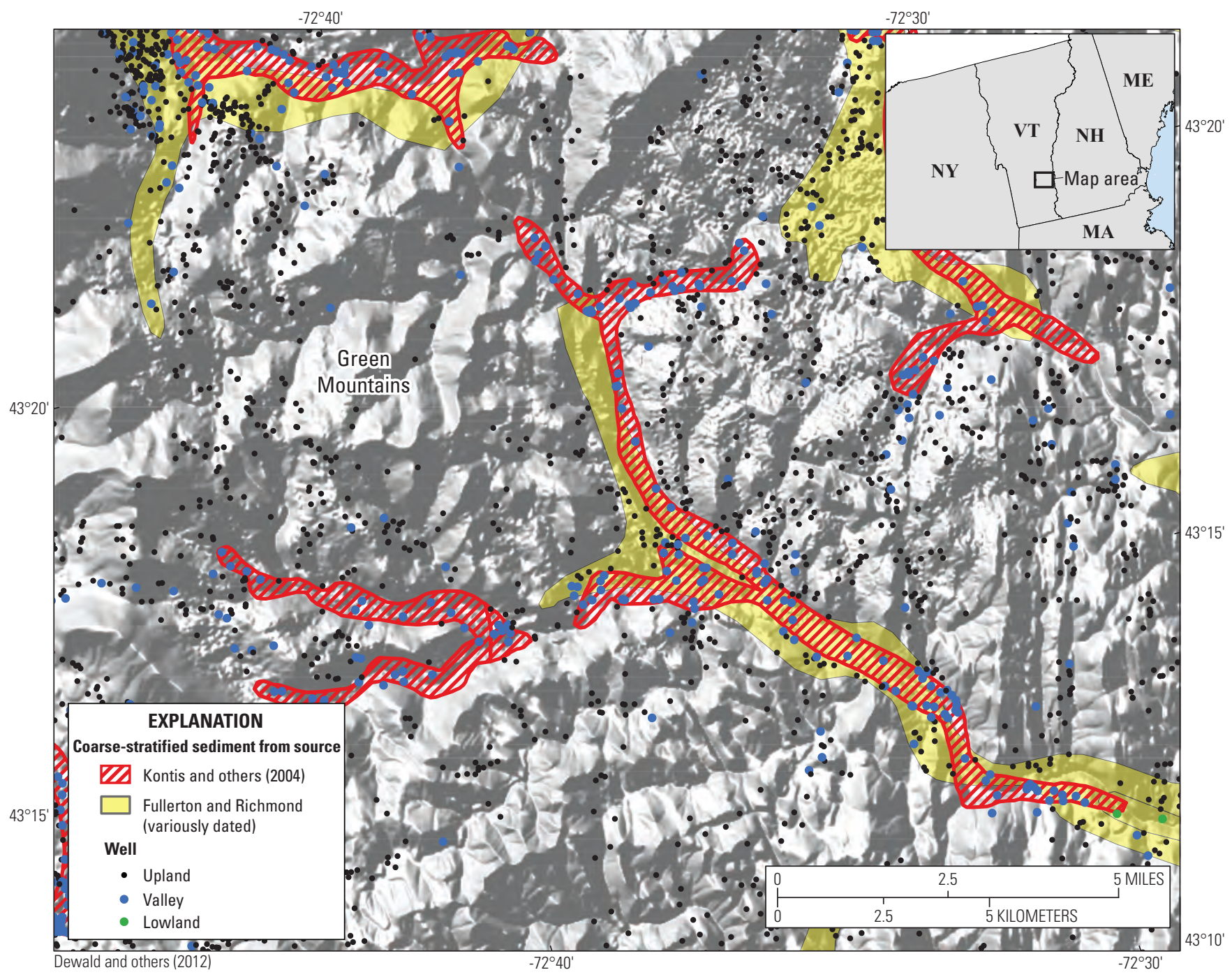

Figure 5. Comparison of extent of coarse-stratified sediment from Kontis and others (2004) and the Glacial Environment and Surficial Sediments geodatabase (Fullerton and Richmond, variously dated), southeastern Vermont. 
the Database of the Geologic Map of North America (Garrity and Soller, 2009) were underlain by sedimentary rocks. Spatial elements in these areas with Litho_class attribute values of "unconsolidated" were changed to "noncarbonate sedimentary rock." Spatial elements with Litho_class attribute values of "unconsolidated" that did not fall within the Midwestern United States were changed to "undetermined."

\section{Interpretations and Applications}

A few inherent qualities of the GESS geodatabase should be considered when interpreting or applying GESS geodatabase attributes and values in a hydrogeologic context. Foremost of these considerations is the scale of the datasets gathered for this investigation and the scale of the aquifer in which the reader may have an interest. The GESS geodatabase was compiled from the Quaternary Atlas and the Surficial Materials Map databases. The Quaternary Atlas was selected as the primary source of geospatial information because of the richness of map units and lithologic data. The 1:1,000,000 scale of the Quaternary Atlas is well-suited for this study and other studies at the national or regional scale; however, if the aquifer in question is set in a geologic unit or surficial sediment deposit having an extent smaller than can be delineated at that scale, that aquifer may not be discretized in the GESS geodatabase. Examples of this can be seen in two areas of the northeastern United States (figs. 5 and 6). In both of these areas, wells in coarse-grained, stratified drift (blue) delineate an aquifer that is not adequately mapped in the GESS geodatabase at the 1:1,000,000 scale. In this region of the country, another dataset is available, which has mapped stratified aquifers in glacial sediments at a more detailed scale (Kontis

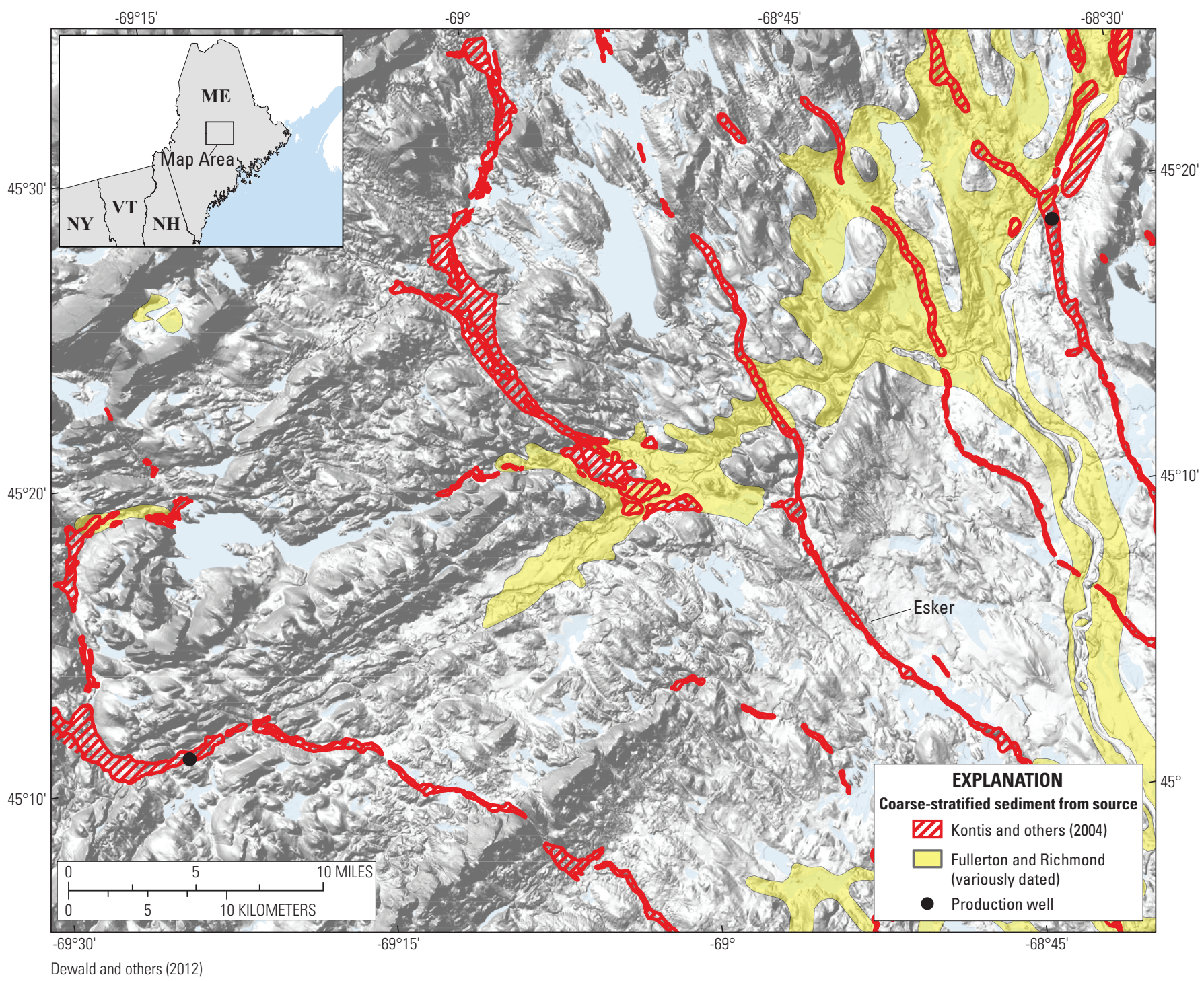

Figure 6. Comparison of extent of coarse-stratified sediment from Kontis and others (2004) and the Glacial Environment and Surficial Sediments geodatabase (Fullerton and Richmond, variously dated), central Maine. 


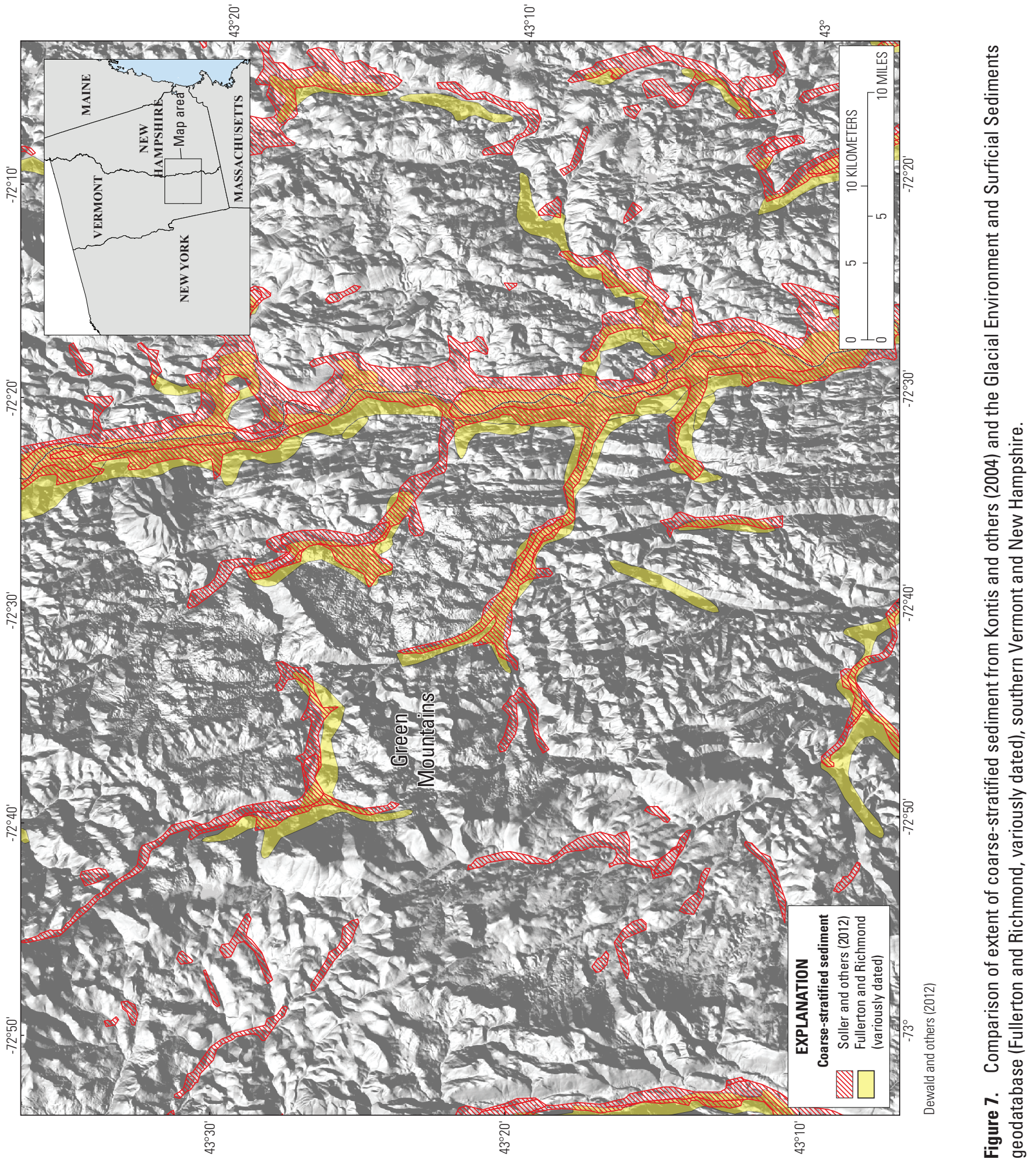


and others, 2004). A modified version of the Kontis and others (2004) database is included in this study — adjustments were made along State boundaries and topographic corrections were added (P. Heisig, USGS, oral commun., 2017). The modified Kontis and others (2004) database, shown in figures 5 and 6, shows a mapped area of coarse-grained, stratified sediments that includes the wells, and so likely is better suited for interpretation of groundwater data in glaciated mountainous areas where the size of aquifers generally is smaller than can be shown at 1:1,000,000 scale.

A second consideration when applying the GESS geodatabase is the existence of discontinuities in mapped features and lithological information at State and Quaternary Atlas $4^{\circ} \times 6^{\circ}$ quadrangle map boundaries. The Quaternary Atlas is a compilation of individual $4^{\circ} \times 6^{\circ}$ quadrangle maps, assembled by different researchers over many years from various databases, which have created data anomalies and discontinuities among the map units shown on the various quadrangles and in attribute values (geocodes, lithologic description, and so on). Two of the more apparent examples of this can be seen in the northeastern United States at the NL-19 Quebec and NK-19 Boston quadrangle boundary and at the New HampshireMassachusetts State boundary, although more subtle anomalies exist in the GESS geodatabase elsewhere (figs. 1 and 2).

Lastly, there may be spatial discrepancies with map spatial elements in the GESS geodatabase and other available geospatial datasets. In some instances, GESS geodatabase map units may appear offset from features from other spatially referenced data. Although these offsets may seem slight in some areas, in other areas the offset must be considered when comparing well data to mapped features in the GESS geodatabase. In figures 5 and 6 , the coarse-grained, stratified sediments of the GESS geodatabase, shown in yellow, coincide for the most part with the wells identified as "valley" wells and with low topographic areas; however, in some areas, coarsegrained, stratified sediments are mapped on the upland surface and incorporate "upland" wells. This discrepancy may produce inaccuracies in the interpretation of well data within the area.

Other smaller-scale datasets exist that may supplement the GESS geodatabase and decrease inaccuracies in application of and interpretations from map unit coverage. In this example, using the modified version of the stratified drift aquifers (Kontis and others, 2004) in an analysis of these aquifers may be more appropriate and yield better interpretive results; the coarse-grained, stratified sediments (modified from Kontis and others, 2004) in figures 5 and 6 are more inclusive of "valley" wells. This comparison is discussed further in Yager and others (2018b).

Other hydrologically significant datasets exist at a scale similar to the GESS geodatabase that can be used to supplement interpretive investigations. Soller and others (2012) mapped coarse-grained, stratified sediments in the United States east of the Rocky Mountains at a 1:1,000,000 scale. The map units in this database were derived from a different map compilation than those used in the GESS geodatabase and, in some parts of the study area, the occurrence of coarse-grained, stratified sediments and other map units may differ. An example of this can be seen in figure 7. A comparison of data from the GESS geodatabase, Soller and others (2012), and the underlying digital elevation model (DEM; Dewald and others, 2012) indicates that, in some areas, mapped units for coarsegrained, stratified sediments in the GESS geodatabase and Soller and others (2012) are more or less coincident, whereas in other areas they are offset yet overlap or they are isolated from one another. Moreover, the comparison of coarsegrained, stratified sediments (of both the GESS geodatabase and Soller and others [2012]) and the valley bottoms as shown in the DEM indicate some discrepancies. Because of these inherent qualities in the GESS geodatabase and in other geospatial databases and maps, caution must be exercised when using the GESS geodatabase to interpret hydrogeologic conditions and aquifer characteristics at a particular well site or at a small scale. The GESS geodatabase was constructed to use the richest geospatial datasets to investigate hydrogeologic trends in aquifers in glacial sediments within broad regions of the United States and at the national scale, but the aforementioned limitations must be recognized.

\section{Hydrogeologic Terranes}

For the glaciated area of the United States, this study used existing maps and knowledge of the regional geology as the basis for a generalized hydrogeologic classification of glacial sediments (Soller and others, 2009, 2012; Soller and Garrity, 2018). This classification was designed to address the potential for encountering coarse-grained sediments (for example, sand and gravel) that may serve as aquifers. Given the emphasis, various regions were delineated, termed "hydrogeologic terranes," and defined using four criteria: overall thickness of Quaternary sediments, with the assumption that greater thickness was associated with a higher likelihood of encountering aquifers in the subsurface; the predominant modes of glacial deposition (for example, ice advance that was mostly unconstrained by other glacial lobes, intermorainal regions between major ice lobes, and so forth); the predominant texture of the surficial sediments; and the geologic age of the sediments, such that sediments of the latest glaciation, Late Wisconsinan, may differ from older glacial sediments in terms of their weathering characteristics and, in turn, hydrogeologic characteristics.

\section{Hydrogeologic Terrane Classification}

The first of those criteria, overall thickness of Quaternary sediments, was used to infer, delineate, and qualitatively rank hydrogeologic complexity that may exist in each terrane. These rankings are highly generalized, used only to give a sense of the relative potential for encountering buried aquifers. Regions with a thin cover (generally less than 15 meters [m]) of Quaternary sediments were assigned a value of "lower" complexity (terrane code 1); regions with thick sediment 
cover (generally greater than $60 \mathrm{~m}$ ) were assigned a value of "higher" complexity (terrane code 3 ); regions with a moderate thickness (between 15 and $60 \mathrm{~m}$, but generally 30 to $40 \mathrm{~m}$ ) were assigned a value of "moderate" complexity (terrane code 2). Two areas of moderate to thick sediment cover were assigned a value (terrane code 4). These areas have unique glacial settings, described in more detail in the "Hydrologic Terranes with Thick, Coarse-Grained, Stratified Quaternary Sediments" section. The correspondence of Quaternary sediment thickness and the hydrogeologic terrane boundaries are shown in figure 8 (Soller and others, 2012).

Figure 8. Hydrogeologic terranes and the thickness and character of glacial sediments in the glaciated conterminous United States. Map is available at https://doi.org/10.3133/ds1090.

Terranes of similar complexity were then evaluated based upon the remaining criteria: mode of deposition, texture, and geologic age. Letter designations were appended to the numeric codes for complexity (for example, 1A, 3C); these denote differences among terranes ranked with similar complexity, and their correspondence to the hydrogeologic terrane boundaries is best illustrated in figure 9 .

Figure 9. Hydrogeologic terranes and the maximum glacial advance of the glaciated conterminous United States. Map is available at https://doi.org/10.3133/ds1090.

\section{Hydrogeologic Terrane Description}

According to the four classification criteria, Quaternary sediments (including sediments of glacial and nonglacial origin) within the glaciated area of the conterminous United States were classified into 17 hydrogeologic terranes (fig. 10). The terranes are grouped by complexity, and their hydrogeologic characteristics are summarized below. More information about the geologic and aquifer characteristics of the terranes and accompanying data sets can be found in Yager and others (2018a,b). Definitions and explanations of terms used in this section is provided in Fullerton and others (2003).

Figure 10. Glacial features, by hydrogeologic terrane, in the glaciated conterminous United States. $A$, terranes $1 A$ and $4 A$ in the northeastern United States; $B$, terranes $1 \mathrm{~B}, 2 \mathrm{~A}$, and $3 \mathrm{~A}$ in western Ohio, Michigan, Indiana, Illinois, eastern Wisconsin, and a small area of northern Kentucky; $C$, terranes 1C, 2C, 2D, $3 C$, and $4 B$ in lowa, southern Minnesota, southeastern South Dakota, northern Missouri, eastern Nebraska and Kansas, and a small area of western Illinois; $D$, terranes $1 \mathrm{D}, 1 \mathrm{E}, 2 \mathrm{~B}$, and $3 \mathrm{~B}$ in Minnesota, Wisconsin, upper Michigan, northern Illinois, and eastern North and South Dakota; $E$, terranes $1 \mathrm{~F}$ and 2E in North and South Dakota and in eastern Montana; and $F$, terrane $1 \mathrm{G}$ in Washington, Idaho, and western Montana. Maps are available at https://doi.org/10.3133/ds1090.

\section{Hydrogeologic Terranes of Lower Complexity}

The following terranes are of lower complexity with a thin (generally less than $15 \mathrm{~m}$ ) cover of Quaternary sediments.

\section{Terrane 1A_Predominantly Late Wisconsinan Sediments in Eastern Ohio Through New England}

Hydrogeologic terrane 1A consists of mostly thin Quaternary sediments and exposed bedrock (mixed sedimentary rocks and igneous and metamorphic rocks). The physiography of this broad area, east of the Appalachian Escarpment in Ohio, varies considerably and includes high relief in several mountain ranges (Adirondack, Catskill, Taconic, Green, and White Mountains), moderate relief in the dissected Appalachian Plateau and New England Uplands, and low relief in lowlands formerly occupied by proglacial lakes or marine waters (fig. 10A).

In general, the terrane is characterized by thin (generally less than $15 \mathrm{~m}$ ) or patchy till and exposed bedrock on the uplands and fine- to coarse-grained stratified sediments in the valleys and lowland areas (figs. 2, 3, and 4). The till is mostly silty to sandy in texture. Till thickness ranges from about $100 \mathrm{~m}$ in the lee of some hills and in valleys transverse to ice flow, to a thin veneer or complete absence over the tops of hills (fig. 8). Where stratified sediments are present on hillsides, it is typically not saturated and serves as a recharge area for stratified sediments in valleys, rather than as an aquifer. A wide range of sediment texture and thickness is indicated by the well logs shown in figure 5 of Soller (1993), but most of the area is underlain by a glacial geologic framework of low stratigraphic complexity.

\section{Terrane 1B-Generally Pre-Late Wisconsinan Sediments in Southern Ohio, Indiana, and Illinois}

Hydrogeologic terrane 1B consists primarily of glacial sediments beyond the Late Wisconsinan ice margin in Ohio, Indiana, and Illinois, and in a small area of Kentucky. Streams in terrane 1B drain upland areas to the Ohio and Mississippi Rivers (fig. 10B). Silty till blankets the uplands and covers about 60 percent of the terrane, whereas stratified sediments are confined mostly to stream valleys and covers most of the remaining area (figs. 2 and 3). Quaternary sediments thin to the south, and sedimentary bedrock is extensively exposed near the limit of glacial ice, which covered the area in Illinoian time. The till in terrane 1B is older and more weathered than till in terranes north of the limit of Wisconsinan glaciation and, therefore, potentially has different hydraulic characteristics. Large areas covered by colluvial sediment are near the southern limit of the terrane. Terrane 1B also includes substantial areas of mostly Late Wisconsinan stratified sediments - outwash and eolian (loess) sediments are present in large valleys, such as the Illinois River, Rock River, and Wabash River valleys, and lacustrine sediment is present in tributaries of the Ohio River. 
Terrane 1C-Older, Partially Eroded Glacial Sediments in Central Missouri

Hydrogeologic terrane 1C consists of older (pre-Illinoian) sediments in northern Missouri and northeastern Kansas (fig. 10C). These sediments are highly weathered and eroded and are composed of mostly silty to clayey till that thins to the south (fig. 3). Sedimentary bedrock is extensively exposed near the limit of glacial ice. This terrane also includes areas of Late Wisconsinan and Holocene alluvial sediment in the Missouri River and tributaries. The pre-Illinoian sediments were deposited within the terrane during several periods of glaciation, and the original glacial landforms have been eroded or covered with eolian sediment (loess). Till covers about one-half of the terrane, whereas large areas near the Missouri and Mississippi Rivers are covered by colluvial sediment and residual soil (fig. 2). Most of the remaining area is covered by alluvial sediment in valleys draining to these major rivers.

\section{Terrane 1D—Older, Partially Eroded Glacial Sediments Around} the Driftless Area

Hydrogeologic terrane 1D includes the Driftless Area and surrounding glaciated areas in Minnesota, Iowa, Wisconsin, and Illinois (fig. 10D). The Driftless Area is so named because the area was not glaciated during the Pleistocene, although stratified sediments were deposited within the area by meltwater streams that drained the adjacent ice margins. Terrane 1D is underlain almost entirely by sedimentary bedrock that is weathered and highly dissected. Within the Driftless Area, these rocks are overlain by colluvial sediment (fig. 2). Glacial sediments in the margins surrounding the Driftless Area are mostly silty till, and stratified sediments are most common north and east of the Driftless Area (fig. 3). To the north and east, the boundary is defined as the limit of Late Wisconsinan ice, whereas to the west the boundary roughly coincides with the western edge of the Paleozoic Plateau; there, the till is preLate Wisconsinan in age, is extensively eroded, and is patchy with extensive areas of exposed bedrock.

Terrane 1E-Late Wisconsinan Sediments Near Lakes Superior and Michigan

Hydrogeologic terrane 1E consists of patchy, Late Wisconsinan sediments on Michigan's Northern Peninsula, on Wisconsin's Door Peninsula, in northeastern Minnesota (fig. 10D). About 60 percent of this terrane is covered by silty to sandy till and has extensive areas of peat and stratified glacial sediments (lacustrine and outwash sediments), especially in Michigan (figs. 3 and 4). Quaternary sediments of this terrane mostly overlie sedimentary, igneous, and metamorphic rocks.
Terrane 1F-Thin Late Wisconsinan Sediments in Montana and North Dakota

Hydrogeologic terrane 1F consists of mostly thin Late Wisconsinan and some older sediments and exposed sedimentary bedrock in eastern Montana and western North and South Dakota (fig. 10E). On the uplands, these sediments are mostly thin (less than $15 \mathrm{~m}$ ) or patchy, silty till, and fine- to coarsegrained stratified sediments with some till in the Missouri River valley and its tributaries (figs. 3 and 8). About 65 percent of the terrane is covered by colluvial sediment (South Dakota) and residual soil (Montana and North Dakota; figs. 2 and 3). A wide range of sediment texture and thickness is indicated by the well logs shown in figure 5 of Soller (1993), but most of the area is underlain by a glacial geologic framework of relatively low stratigraphic complexity.

\section{Terrane 1G—Residual Soils and Sediments From the Cordilleran Ice Sheet}

Hydrogeologic terrane $1 \mathrm{G}$ extends from the Rocky Mountains in Montana, west to Puget Sound in Washington (fig. $10 F$ ). This broad area is characterized mainly by residual soil in mountainous areas and glacial sediments deposited by the Cordilleran ice sheet and alpine glaciers, including patchy till on the uplands and fine- to coarse-grained stratified sediments in the valleys (figs. 2 and 3). This terrane is underlain by various types of bedrock, ranging from Archean metamorphic rock in Montana to Tertiary volcanic and sedimentary rock in the Puget Sound lowlands (fig. 4). Quaternary sediments in the lowlands compose the Puget Sound aquifer system and are underlain by Tertiary sediments. The physiography of this terrane varies considerably and includes high relief in the Cascade and Rocky Mountain ranges, moderate relief in the central Washington Okanogan Highlands, and low relief near Puget Sound (fig. 10F).

\section{Hydrogeologic Terranes of Moderate Complexity}

The following terranes are of moderate complexity with a cover of 30 to $40 \mathrm{~m}$ of Quaternary sediments.

Terrane 2A—Predominantly Late Wisconsinan Sediments, Notably With Buried Valley Systems

Hydrogeologic terrane 2A consists of a nearly continuous cover of Quaternary sediments that overlies sedimentary bedrock and extends from Wisconsin, through Illinois, Indiana, and Ohio, and into Michigan (fig. 10B). Silty till predominates on the uplands and covers 70 percent of the terrane (fig. 3). Stratified sediments are mostly confined to stream valleys, except along the shores of Lakes Michigan, Erie, and Huron, where broad areas of proglacial lacustrine sediment cover 15 percent of the terrane (figs. 2 and 3). Clayey till occupies lowlands southwest of Lakes Michigan and Erie, which are remnants of advances of the Michigan and Huron-Erie ice lobes (fig. 3). A succession of end moraines in 
Illinois, Indiana, and Ohio mark positions where these lobes stalled during the glacial retreat (fig. 2). Most of this terrane is underlain by carbonate bedrock (fig. 4); bedrock aquifers are hydraulically connected to Quaternary aquifers, especially in eastern Indiana and western Ohio, where together they are treated as a single aquifer system (Eberts and George, 2000).

Quaternary sediments at land surface are almost entirely of Late Wisconsinan age; Illinoian and older glacial sediments are preserved at depth (for example, within the MahometLafayette aquifer system of Ohio, Indiana, and Illinois) and over other bedrock topographic lows (fig. 10B). The variability of sediment texture, lithology and hydrogeologic characteristics is higher compared to the lower complexity terranes described in previous sections. The example well logs in Soller (1998), especially for Illinois and Indiana, give some indication of this variability at depth. The southern limit of this terrane is defined as the farthest extent of Late Wisconsinan glaciation. The eastern and northern boundaries are arbitrarily placed within transitional areas between adjacent terranes.

Terrane 2B - Late Wisconsinan Sediments From Lake Superior Lobe

Hydrogeologic terrane 2B consists of a nearly continuous cover of mostly Late Wisconsinan sediments deposited by the Lake Superior lobe over sedimentary, igneous, and metamorphic rocks in northern Wisconsin and eastern Minnesota (fig. 10D). Silty to sandy till covers 55 percent of the terrane (figs. 2 and 3). The remainder is covered by an extensive area of coarse-grained stratified sediments, primarily in the eastern part of the terrane and southwest of Lake Superior (fig. 3). The example well logs in Soller (1998) for Wisconsin convey the level of complexity of sediment deposits in this terrane. The southern limit of the terrane is defined as the farthest extent of Late Wisconsinan glaciation. Other boundaries are arbitrarily placed within transitional areas between adjacent terranes.

Terrane 2C-Late Wisconsinan Sediments in the Des Moines Lobe

Hydrogeologic terrane 2C consists of a continuous cover of Quaternary sediments that overlies sedimentary bedrock in Iowa and southern Minnesota (figs. 4 and 10C). Silty till predominates on the uplands and covers 80 percent of the terrane, whereas coarse-grained, stratified sediments are confined generally to stream valleys (figs. 2 and 3). Quaternary sediments at land surface are of Late Wisconsinan age deposited by ice of the Des Moines lobe that advanced to the east of the Prairie Coteau; at depth, older sediments are preserved (fig. 10C). The southern and eastern limit of this terrane is defined as the farthest extent of Late Wisconsinan glaciation. Other terrane boundaries are arbitrarily placed within transitional areas between adjacent terranes.

\section{Terrane 2D—Older Sediments in lowa and Kansas}

Hydrogeologic terrane 2D consists of older (mostly preIllinoian) sediments that overlie sedimentary bedrock south of the Late Wisconsinan ice margin in Kansas, Missouri, Iowa, and southeastern Minnesota (fig. 10C). Silty to clayey till predominates on the uplands and covers nearly 80 percent of the terrane, becoming mostly silty to the east (figs. 2 and 3). Eolian sediment (loess) blankets the uplands to a notable degree, exceeding $6 \mathrm{~m}$ in thickness in the western part of the terrane. Coarse-grained, stratified sediments (mostly alluvial sediment) are generally confined to stream valleys. Example well logs in Soller (1997; IA-1, IA-3, IA-4, and IA-5) give some indication of this variability at depth. The boundaries are arbitrarily placed within transitional areas between adjacent terranes, except where it abuts terrane $2 \mathrm{C}$; there it is defined as the maximum extent of Late Wisconsinan glaciation.

\section{Terrane 2E-Late Wisconsinan Sediments in the Dakotas}

Hydrogeologic terrane 2E consists of a nearly continuous cover of Quaternary sediments that overlies sedimentary rocks in eastern North and South Dakota (fig. 10E). Silty till predominates on the uplands and covers 70 percent of the terrane (figs. 2 and 3). Broad areas of coarse- and fine-grained stratified sediments also are present on some uplands, which are dotted with prairie potholes, or kettle lakes. Fine-grained lacustrine sediment from proglacial lakes occupy lowlands along the Souris and James Rivers (figs. 2 and 10E). Quaternary sediments at land surface are mostly of Late Wisconsinan age, whereas older sediments are preserved beyond the Late Wisconsinan ice margin and at depth. Example well logs in Soller (1997; ND-1 and ND-2) give some indication of variability in areas with a thicker sediment cover. The boundaries are arbitrarily placed within transitional areas between adjacent terranes.

\section{Hydrogeologic Terranes of Higher Complexity}

The following terranes are of higher complexity with a thick (more than $60 \mathrm{~m}$ ) cover of Quaternary sediments.

Terrane 3A-Interlobate Area in Southern Michigan Between Lake Michigan, Saginaw, and Lake Huron-Erie Lobes

Hydrogeologic terrane 3A consists of thick sequences of Quaternary sediments composed of multiple till sheets and intercalated stratified sediments (mostly sands and gravels) that overlie sedimentary bedrock Michigan's Southern Peninsula (figs. 2, 3, and 10B). This terrane is roughly delineated by the interlobate region between the ice sheets of the Michigan and Huron-Erie lobes. Sediment thickness commonly exceeds $100 \mathrm{~m}$ in the northern part of the terrane (fig. 8). Till is mostly sandy to silty in texture and covers 45 percent of the terrane (fig. 2). Stratified sediments are widespread at land surface and is mostly coarse-grained, except for fine-grained, lacustrine sediment in the lowlands southwest of Saginaw Bay (figs. 8 and 10B). The example well logs in Soller (1998) for Michigan convey the level of complexity of sediments in this terrane. The boundaries of this terrane mainly are based on the sediment thickness (fig. 8). 
Terrane 3B-Interlobate Area in Minnesota Between Labrador and Keewatin Laurentide Centers

Hydrogeologic terrane 3B consists of thick sequences of Quaternary sediments composed of multiple till sheets and intercalated stratified sediments (mostly sands and gravels) over sedimentary, igneous, and metamorphic rock in Minnesota and the eastern Dakotas (figs. 2, 3, and 10D). Quaternary sediments were deposited by ice from the western and eastern centers of ice accumulation in the Laurentide ice sheet (Leverett and Sardeson, 1932; Mickelson and others, 1983). Ice flowed south from the western center in the Red River lobe, whereas ice flowed southwest from the eastern center in the Lake Superior lobe (lobes were centered in Canada north of the Red River and north of Lake Superior, respectively; fig. 10D). The interaction between these ice lobes formed a thick, highly complex stack of sediments that is poorly delineated in the subsurface. Sediment thickness commonly exceeds $100 \mathrm{~m}$ throughout the terrane (fig. 8). Till is silty sandy to clayey in texture and covers 45 percent of the terrane (figs. 2 and 3). Stratified sediments are mostly outwash sediment with some lacustrine sediment in the Red River valley, the former location of glacial Lake Agassiz (fig. 10D). Extensive deposits of peat in northern Minnesota cover 7 percent of this terrane.

\section{Terrane 3C-Prairie Coteau}

Hydrogeologic terrane $3 \mathrm{C}$ consists of thick sequences of Quaternary sediments beneath the Prairie Coteau region (eastern South Dakota, southwestern Minnesota, and northwestern Iowa), composed of multiple till sheets and intercalated stratified sediments (mostly sands and gravels) over sedimentary bedrock (fig. 10C). Quaternary sediments beneath the Prairie Coteau were deposited from interaction of ice in the interlobate region between the James and Des Moines lobes. Sediment thickness commonly exceeds $100 \mathrm{~m}$, and silty till predominates at land surface and covers 80 percent of the terrane (figs. 2 and 3). Most of the coarse-grained sediments are outwash sediment deposited in the valleys of the Big and Little Sioux Rivers, but extensive ice-contact sediment mantles the uplands in the northern part of the terrane. The example well $\log$ in Soller (1997) for South Dakota conveys the level of complexity of sediments in this terrane (Soller, 1997). The boundaries of the terrane are based mostly on sediment thickness and topographic expression of the Prairie Coteau region (figs. 8 and 10C).

\section{Hydrogeologic Terranes with Thick, Coarse-Grained, Stratified Quaternary Sediments}

The following terranes contain a thick (70 to $90 \mathrm{~m}$ ) cover of Quaternary sediments and have unique glacial settings.

\section{Terrane 4A—Long Island and Cape Cod}

Hydrogeologic terrane 4A includes glaciated areas on Cape Cod and Long Island (fig. 10A). Quaternary aquifers beneath Long Island and Cape Cod are bounded by saltwater. On Long Island, the glaciated area extends from the north shore to the Ronkonkoma terminal moraine, which bisects the island west to east. Outwash plains that extend south of the moraine to the south shore are excluded in our definition of the glaciated United States. All of Cape Cod is included, however, because geologic units below the Quaternary sediments are not used as aquifers like they are on Long Island. Both areas are blanketed by thick morainal and intermorainal glacial sediments, and some thin postglacial alluvial, organic (peat), and eolian sediment are present in lowland areas. Morainal sediments mark the highest elevations on these islands. Maximum relief is about $93 \mathrm{~m}$ on Cape Cod and about $122 \mathrm{~m}$ on Long Island.

Quaternary sediments on Cape Cod are primarily outwash and ice-contact sands and gravels that directly overlies bedrock. Glacial deposition is the result of the interaction among the Buzzard's Bay, the Cape Cod Bay, and the South Channel ice lobes (Oldale and Barlow, 1986). Deposition from the Buzzard's Bay and the Cape Cod Bay lobes formed the high topography in western and northwestern Cape Cod, whereas deposition from the Cape Cod Bay and the South Channel lobes formed the low topography in the north-south "arm" of eastern Cape Cod. Outwash plains on Cape Cod cap a deltaic, downward fining sequence (Masterson and others, 1997; Walter and Whealon, 2005). The deltas were deposited into a proglacial lake that was dammed by a moraine near Martha's Vineyard and Nantucket to the south.

Quaternary sediments on Long Island overlie the dissected surface of unconsolidated Cretaceous-age sediments that contain two productive aquifers, the Magothy and the Lloyd aquifers (Smolensky and others, 1989). The Harbor Hill and the Ronkonkoma moraines form the north and south forks of Long Island, respectively, and coalesce into a single moraine across the western one-third of the island. The moraines are underlain by alternating till and outwash or ice-contact sediments. Intermorainal areas are underlain by outwash and interbedded lacustrine sediments (Krulikas and Kozalka, 1983).

\section{Terrane 4B—Eastern Nebraska}

Hydrogeologic terrane 4B consists of coarse-grained, stratified Quaternary sediments in eastern Nebraska (figs. 3 and $10 C$ ). Sediments were derived from the Laurentide ice sheet to the east and from the glacial and fluvial systems in the Rocky Mountains to the west. Terrane 4B also includes buried, pre-Illinoian till from the Laurentide ice sheet. The western boundary of the terrane is positioned just west of the till, whose position and geometry is arbitrary; hence the boundary is approximate and represented on the maps as an undulating line (fig. 2). Alluvial sediment covers 60 percent of the terrane, and silty clayey till covers most of the remainder (figs. 2 and 3). 


\section{Interpretive and Application Limitations}

Any classification should be used with caution and understanding of the caveats. This is especially true for highly generalized, regional ones such as these hydrogeologic terranes. Here are the two principal caveats:

Variability within a terrane.-To achieve a manageable number of elements in this classification, hydrogeologic variations within a delineated terrane are acknowledged as likely. These variations are commonly indicated by well logs whose profiles do not match the generalized description for the terrane.

Similarity between terranes, especially near the boundaries.-Certain terrane boundaries are based on well-delineated geologic criteria (for example, the limit of Late Wisconsinan ice). Many other boundaries are less precisely positioned, on the basis of regional changes in overall thickness of Quaternary sediments or along regional trends of end moraines. In certain cases, the boundaries were arbitrarily drawn along State boundaries. The terrane boundaries therefore should be considered as "fuzzy" in nature, positioned in a very general sense, with considerable similarities shared by the geologic framework near the boundary on both sides.

\section{Public-Supply Groundwater Use Datasets}

Records of public-supply groundwater usage were collected for parts of 24 States within the glaciated conterminous United States (excluding Kentucky) for water systems that withdraw groundwater through wells and springs. The 71,267 public water systems that were identified included community systems, noncommunity systems with at least 15 service connections, and systems that regularly serve at least 25 individuals daily for at least 60 days each year. The status of water sources, whether active or inactive, was based on available State records. The compilation of groundwateruse information prepared for this study includes withdrawals from wells that derive water from surface-water infiltration, and groundwater delivered from combined systems that derive water from both groundwater and surface-water sources.

Water-use data, listed as a system-level table that lists information by system and as a source-level table that lists information by well, are published in Haj and others (2018). The water-use records include identifiers for the U.S. Environmental Protection Agency (EPA) and State agency databases, the ownership and type of public water system (PWS), the location and the population served by the system, withdrawal rates, well construction data, and the source aquifer of the water supply. The water-use records were sought for the reporting years 2009 to 2013 and averaged to compare with the 2010 data from the most recent USGS national water-use compilation (Maupin and others, 2014). The desired data for each record typically were not available from a single database. As a result, information on withdrawal rates, well construction, and aquifer source were compiled from and crossreferenced to those in State and Federal databases. A summary of public-supply groundwater usage by State is presented in table 4 (in back of report), and the list of attributes included in the system and source tables is presented in table 5 .

Most of the water-use records have location and population served data obtained from the EPA Safe Drinking Water Information System (SDWIS; U.S. Environmental Protection Agency, 2013). Additional records and information concerning SDWIS locations, for example well construction or source water databases, were obtained from State resources. Missing location data were approximated based on facility addresses or the central coordinates of the community served. Missing data on the population served were back-calculated from withdrawal rates or approximated by the median population served value for the public water system type within the State. In cases where population data were not available a default value of 25 persons was assumed, based on the minimum population required for a public water system. It is possible that some populations were double counted if a system sold water to another system, or for systems with groundwater and surface-water supplies that report combined values for the populations served.

Reporting of groundwater-use data varies among the States; for example, the withdrawal-rate reporting threshold ranged from 38 to 380 cubic meters per day, and records were reported by either the individual source or for the entire water system. Withdrawal data were obtained from the States' water-use registration, permitting, reporting, or allocation programs. Some withdrawal data were supplemented with information from the USGS Site-Specific Water-Use Data System (SWUDS; U.S. Geological Survey, 1997) and by direct requests to State agencies or through various online resources, such as water-quality and water diversion reports. Withdrawals from small water systems typically are not recorded and were estimated based on population served and a per capita wateruse coefficient.

Per capita water-use values were obtained from the USGS Aggregate Water-Use Data System (AWUDS) database for 2010 (U.S. Geological Survey, 1998) and used either a county per capita value or a weighted average per capita for the State based on county populations. A public-supply per capita was commonly used to estimate withdrawals for mixed-use community water systems (for example, a city that delivers water to industrial, commercial, and residential customers). USGS public-supply data in AWUDS typically only included water-use data for community water systems that meet State reporting requirements and, in some cases, captured only the larger municipal water systems. Public-supply per capita water-use values ranged from 0.11 to 2.0 cubic meters per person per day $\left(\mathrm{m}^{3} \mathrm{ppd}\right)$. Domestic per capita water-use values that ranged from 0.12 to $0.74 \mathrm{~m}^{3} \mathrm{ppd}$ were estimated for residential community water systems that mainly serve households. Per capita values for transient, noncommunity systems (such as schools and offices) and nontransient, noncommunity systems (such as hotels and restaurants) were calculated from Vickers' industrial, commercial, and institutional benchmark data for similar public-supply uses (Vickers, 2001). 
Table 5. Fields included in system-level and source-level water-use tables.

[EPA, U.S. Environmental Protection Agency; ID, identifier]

\begin{tabular}{|c|c|c|c|}
\hline Field name & Table & Description & Values \\
\hline AQ_CODE_TX & $\begin{array}{l}\text { System and } \\
\text { source }\end{array}$ & Type of aquifer source & $\begin{array}{l}\text { Bedrock, bedrock aquifer type (consolidated rock, including fractured } \\
\text { crystalline rock). } \\
\text { Cretaceous, unconsolidated deposits of the Cretaceous Period }{ }^{1} \text {. } \\
\text { Mixed, water source or system open to multiple aquifer sources }{ }^{2} \text {. } \\
\text { Quaternary, unconsolidated materials of the Quaternary Period. } \\
\text { Unknown, unknown aquifer type. } \\
\text { NA, not available, used for water sources listed as a cross-connection } \\
\text { to a neighboring water system. }\end{array}$ \\
\hline CC_FLAG & $\begin{array}{l}\text { System and } \\
\text { source }\end{array}$ & Cross-connection data flag & $\begin{array}{l}\text { Y, yes; groundwater is entirely purchased from a neighboring water } \\
\text { system(s). } \\
\text { N, no; no purchases are made, the system is solely supplied by its } \\
\text { own groundwater sources. } \\
\text { B, both; water supply is augmented by a purchase from neighboring } \\
\text { water system(s). }\end{array}$ \\
\hline COUNTY1 & $\begin{array}{l}\text { System and } \\
\text { source }\end{array}$ & $\begin{array}{l}\text { Name of county served by } \\
\text { water system }\end{array}$ & Primary county of water service. \\
\hline CTBG_GEOID & Source & $\begin{array}{l}\text { Location of water source } \\
\text { assigned to a Census } \\
\text { block group }\end{array}$ & $\begin{array}{l}\text { U.S. Census Bureau's TIGER/Lines shapefile for } 2015 \text { block groups. } \\
\text { Field called "GEOID" represents the geographical area unit. Spa- } \\
\text { tial data available at https://www.census.gov/cgi-bin/geo/shape- } \\
\text { files/index.php. }\end{array}$ \\
\hline CTCS_GEOID & System & $\begin{array}{l}\text { Location of water system } \\
\text { assigned to a Census } \\
\text { county subdivision }\end{array}$ & $\begin{array}{l}\text { U.S. Census Bureau's TIGER/Lines shapefile for } 2015 \text { county sub- } \\
\text { divisions. Field called “GEOID” represents the geographical area } \\
\text { unit. Spatial data available at https://www.census.gov/cgi-bin/geo/ } \\
\text { shapefiles/index.php. }\end{array}$ \\
\hline POP_FLAG & System & Population served data flag & $\begin{array}{l}\text { Y, population served value likely contains persons served by surface } \\
\text { water or may include double-counting of persons that purchase } \\
\text { groundwater from another system. } \\
\mathrm{C} \text {, population served value of a mixed water systems (has both } \\
\text { surface- and groundwater sources) was adjusted to account for } \\
\text { persons only served by groundwater. } \\
\mathrm{N} \text {, population served by groundwater. }\end{array}$ \\
\hline POP_X-CTY & System & $\begin{array}{l}\text { Multi-county water service } \\
\text { data flag }\end{array}$ & $\begin{array}{l}\text { Y, population served by the public-water system extends across state } \\
\text { or county boundaries. } \\
\mathrm{N} \text {, population served by the public-water system is within one county. }\end{array}$ \\
\hline POPSRV_PERS & System & Population served value & $\begin{array}{l}\text { Population, by groundwater, in persons. See field called } \\
\text { "POP_FLAG" for data qualifiers. }\end{array}$ \\
\hline PWS_ID & $\begin{array}{l}\text { System and } \\
\text { source }\end{array}$ & $\begin{array}{l}\text { Public-water system } \\
\text { identifier }^{4}\end{array}$ & EPA's Safe Drinking Water Information System (SDWIS) database. \\
\hline PWS_NAME & $\begin{array}{l}\text { System and } \\
\text { source }\end{array}$ & Public-water system name ${ }^{5}$ & EPA's Safe Drinking Water Information System (SDWIS) database. \\
\hline
\end{tabular}


Table 5. Fields included in system-level and source-level water-use tables.-Continued

[EPA, U.S. Environmental Protection Agency; ID, identifier]

\begin{tabular}{|c|c|c|c|}
\hline Field name & Table & Description & Values \\
\hline PWS_TYPE & $\begin{array}{l}\text { System and } \\
\text { source }\end{array}$ & Public-water system type & $\begin{array}{l}\text { CWS: community. } \\
\text { NTNCWS: nontransient, noncommunity }{ }^{6} \text {. } \\
\text { TNCWS: transient, noncommunity }{ }^{7} \text {. }\end{array}$ \\
\hline REC_NO & Source & Source record number & Sequential record number of the source-level table starting at 1 . \\
\hline SELLER1_PWSID & System & PWS_ID of a neighboring & First listed PWS_ID selling water to the local water system. \\
\hline SELLER2_PWSID & & water system from which & Second listed PWS_ID selling water to the local water system. \\
\hline SELLER4_PWSID & & & Fourth listed PWS_ID selling water to the local water system. \\
\hline SELLER5_PWSID & & & Fifth listed PWS_ID selling water to the local water system. \\
\hline SELLER6_PWSID & & & Sixth listed PWS_ID selling water to the local water system. \\
\hline SRC_STATUS & Source & $\begin{array}{l}\text { Groundwater source produc- } \\
\text { tion status in } 2010\end{array}$ & $\begin{array}{l}\text { A, active. } \\
\text { E, active but reserved for backup or emergency use. } \\
\text { I, inactive. } \\
\text { L, legacy (water system no longer uses their wells but purchases } \\
\quad \text { groundwater from another system; however, the purchased amount } \\
\text { was not reported in the seller's reported withdrawal data). } \\
\mathrm{R} \text {, assumed to be active. } \\
\mathrm{T} \text {, to be abandoned. } \\
\mathrm{X} \text {, abandoned. }\end{array}$ \\
\hline SRC_TYPE & Source & Groundwater source type & $\begin{array}{l}\text { WL, well. } \\
\text { SP, spring. } \\
\text { CC-GW, groundwater purchased through a cross-connection to } \\
\text { neighboring water system(s). }\end{array}$ \\
\hline SRC_WD-GW_MGY & Source & $\begin{array}{l}\text { Withdrawal from a ground- } \\
\text { water source }\end{array}$ & Well or spring, in million gallons per year. \\
\hline STATE1 & $\begin{array}{l}\text { System and } \\
\text { source }\end{array}$ & State & $\begin{array}{l}\text { Primary state of water service represented by the 2-letter U.S. Postal } \\
\text { Service abbreviation. }\end{array}$ \\
\hline WDEPTH_FT & Source & Well depth & In feet below land surface. \\
\hline WU_METH & $\begin{array}{l}\text { System and } \\
\text { source }\end{array}$ & $\begin{array}{l}\text { Method used to obtain the } \\
\text { groundwater-use value }\end{array}$ & $\begin{array}{l}\text { R, Reported data. } \\
\text { E, Estimated value. } \\
\text { B, Combination of both approaches (for example, system had re- } \\
\text { ported withdrawals for some but not all of its groundwater sources } \\
\text { or system had reported total withdrawal but no withdrawal data by } \\
\text { its sources). }\end{array}$ \\
\hline
\end{tabular}

${ }^{1}$ For example, Magothy and Llyod aquifers of Long Island, New York.

${ }^{2}$ For example, Quaternary and bedrock, Quaternary and Cretaceous.

${ }^{3}$ Used if system withdrawals were estimated.

${ }^{4}$ Unassigned values given project-specific sequential ID beginning sys00001.

${ }^{5}$ Preference was given to State-designated system names when merging records from multiple data sources.

${ }^{6}$ For example, schools and offices.

${ }^{7}$ For example, hotels and restaurants.

${ }^{8}$ Indicates that water is supplied and accounted for by a neighboring water system.

${ }^{9}$ Systems that serve surface water exclusively were not included. 
The transient noncommunity water use per capita value was $0.06 \mathrm{~m}^{3} \mathrm{ppd}$ and the nontransient, noncommunity water use per capita value was $0.19 \mathrm{~m}^{3} \mathrm{ppd}$.

Assigning the source aquifer, either Quaternary sediments or bedrock, for each water system was difficult because few States provide an aquifer code in their water-use reporting databases and well construction data were often not available or readily cross-referenced. State websites and map services were searched to obtain information on aquifer resources, including maps of depth to bedrock, Quaternary sediment thickness, and surficial geology. In cases where source aquifer or well construction data were available, the records were matched and classified. If well construction data were available, then assignments were based on well depth in comparison to the available maps or spatial proximity to nearby adjacent well records with more complete data.

If well construction data were not available, two other methods were used to assign the source aquifer. For counties where a predominant aquifer source could be determined from either other public-supply well records that contained aquifer codes or additional data from the USGS National Water Information System (NWIS; U.S. Geological Survey, 2015), the aquifer sources was assigned to the County's predominant aquifer source. If no predominant aquifer source was apparent, then the aquifer source was assigned using a map of Quaternary sediment thickness (Soller and Garrity, 2018). Water systems were assigned to either a bedrock aquifer or a Quaternary aquifer if the well was located where the sediment thickness was thin or thick (less than $15 \mathrm{~m}$ or greater than $60 \mathrm{~m}$, respectively). The aquifer source was not assigned for the 7,276 remaining water systems where the sediment thickness was between 15 and $60 \mathrm{~m}$.

The public water system records were checked to improve quality and completeness of inventories and associated data. Several checks were implemented, including searching for outliers, missing, or irregular data entries; removing duplicate records that resulted from the merger of State and Federal records; and reviewing the accuracy of data codes, units, and water-use estimation methods that were based on various types of public water systems. Per capita use values were calculated for each system and evaluated to determine whether the reported withdrawal rates were reasonable. Common errors that were corrected include population counts for facilities that deliver water to other facilities, populations that were counted at the source and destination facilities, and withdrawal rates for mixed-use supplies that provide water for manufacturing.

The completed inventory represents the best estimates of public-supply groundwater withdrawals by source aquifer, on the basis of the current state of scientific knowledge and data available. Annual public-supply, groundwater withdrawals in 2010, aggregated by State, are compared with estimates from Maupin and others (2014; fig. 11). The total withdrawals estimated for the glaciated United States are similar (5,527 million cubic meters per year in this study and 5,082 million cubic meters per year in Maupin and others, [2014]), but the

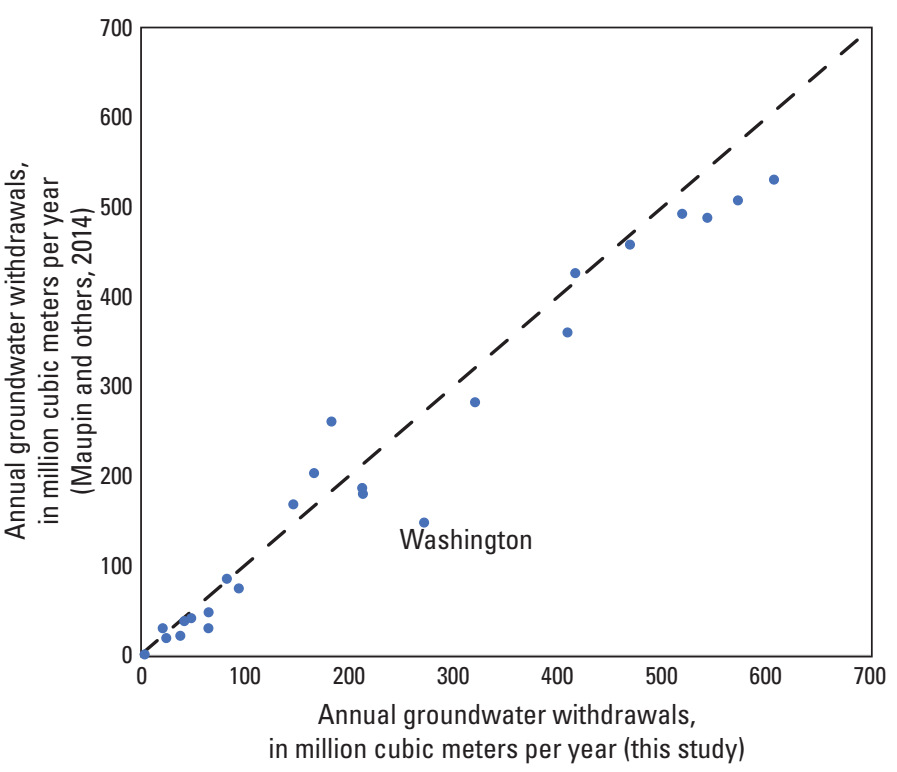

Figure 11. Comparison of public-supply groundwater withdrawals in the glaciated conterminous United States estimated by this study and by Maupin and others (2014).

withdrawals estimated for some States (for example, Washington) are different. In some cases, public-water supplies in the SWUDS database used in this study were mislabeled as surface water, rather than groundwater, leading to under estimation. In other cases, per capita values used to estimate groundwater withdrawals by Maupin and others (2014) were too large, particularly in areas where water supplies serve nonpublic users, resulting in overestimation of actual withdrawals for public supply. Additional information, beyond the scope of this study, is required to account for all these differences.

\section{Lithologic Database Derivatives}

A lithologic database for the glaciated conterminous United States was compiled from State well records, and the well records were standardized so that the lithologic information used a consistent terminology (Bayless and others, 2017). The part of the database used for this study contains $1,565,349$ records in 24 States in the glaciated conterminous Unites States (excluding Kentucky), of which 740,727 are for wells that are for the purpose of withdrawing water. Most of the records for water wells in the database are for domestic wells. The data density varies: about 85 percent of the well records are in the Midwest, 13 percent are in the Northeast (terranes $1 \mathrm{~A}$ and $4 \mathrm{~A}$ ), and 2 percent are in the Northwest (terrane 1G; fig. 12). The data density reflects areas where groundwater usage is highest (terranes $1 \mathrm{~B}, 2 \mathrm{~A}$ and $3 \mathrm{~B}$ ), and States that possess the most complete well records (for example, Vermont). Three States, Connecticut, Nebraska, and Michigan, do not record the usage of the well, so no information is available concerning the distribution of water wells. 
Figure 12. Density of lithologic logs aggregated on a 5-kilometer grid in the glaciated conterminous United States. Map is available at https://doi.org/10.3133/ds1090.

The lithologic database contained the top and bottom depth for intervals with the lithologic descriptions (lithologic logs), as well as various other items describing the wells on a State-by-State basis. A composite database was created by combining all the States and aggregating the individual intervals for each well into a single record. The well locations were intersected with the spatial datasets of the hydrogeologic terranes and from the GESS geodatabase. Attributes were added to the records for each well in the lithologic database describing the hydrogeologic terrane, the complexity of the hydrogeologic terrane, the surficial map unit, the texture of the surficial unit, whether the unit was stratified and coarse, and the bedrock geology classification (table 6). Characteristics of the Quaternary sediments encountered by the wells were calculated from the lithologic data, as described below. The metrics that were compiled from the lithologic database are listed in table 6. Median values of each metric were aggregated using a 1-km geospatial grid cell to deemphasize clusters in the data. The gridded lithologic database can be accessed at Haj and others (2018).

The Quaternary sediment thickness was computed if the depth to bedrock was noted in the lithologic log. Not all wells penetrated the entire thickness of Quaternary sediments, especially in areas where the sediments are thickest, such as in terranes of high complexity (codes 3 and 4 ). In the case where the log did not show bedrock contact, the thickness was estimated from the maps of the Quaternary sediment thickness.
For most of the area, the depth of the Quaternary sediments from Soller and Garrity (2018) was used. For the Puget Sound area, the bedrock surface from Jones (1999) was used. In a small area near Colville, Washington, the depth of the Quaternary sediments came from a groundwater-flow model (Ely and Kahle, 2004). In areas of eastern Washington, Idaho, and Western Montana, no previous estimates of the Quaternary sediment thickness were available on a regional basis.

Several metrics that characterize the Quaternary sediment and aquifer-material intervals (at least $3 \mathrm{~m}$ of coarse-grained material) penetrated by the wells were computed from the lithologic logs. For the purpose of these computations, the Quaternary sediments were classified into fine-grained (clay and silt) and coarse-grained (sand and gravel) categories. Aquifer material was considered to be $3 \mathrm{~m}$ or more of contiguous coarse-grained material within a lithologic log with no more than $0.5 \mathrm{~m}$ of intervening fine-grained material. The number of occurrences of aquifer-material intervals in each $\log$ was counted. The aquifer thickness, interval depth, thickness of the confining layer (if present), and the amount of fine-grained material within the aquifer-material interval were computed. In the case where multiple intervals were present, the values for the thickest (main) and deepest (bottom) intervals were recorded. In cases where only one interval of aquifer material was present, the main and bottom intervals are the same. Additional metrics were computed as to whether the aquifer-material interval was confined by at least 7.5, 15 , or $30 \mathrm{~m}$ of fine-grained material. An important caveat is that some aquifer-material intervals shown by lithologic logs could be partially saturated, so the computed aquifer thickness would be greater than the saturated thickness of the aquifer. 
Table 6. Characteristics of sediment and aquifer-material intervals obtained from lithologic logs.

$[\mathrm{km}$, kilometer; $\mathrm{m}$, meter; $<$, less than; $>$, greater than $]$

\begin{tabular}{|c|c|}
\hline Variable & Definition \\
\hline \multicolumn{2}{|r|}{ Log attribute } \\
\hline ID & Well identifier. \\
\hline State & State location. \\
\hline Grid ID & Sequential number in $1-\mathrm{km}$ grid. \\
\hline Terrane & Hydrogeologic terrane. \\
\hline WellDepth & Depth of lithologic log below land surface. \\
\hline BedrockDepth & Depth bedrock below land surface. \\
\hline BedrockDepthSource & $\begin{array}{l}\text { Source of bedrock-depth data; from log, or estimated from Jones (1999), Ely and Kahle (2004), or } \\
\text { Soller and Garrity (2018). }\end{array}$ \\
\hline PercentLogPenetration & Percent penetration of log through Quaternary sediment. \\
\hline NumberAquifers & Number aquifer-material intervals. \\
\hline WaterTableAquiferThick & Thickness of aquifer-material interval overlain by $<7.5 \mathrm{~m}$ of fine-grained material. \\
\hline ConfinedAquifer & Aquifer-material interval overlain by $>7.5 \mathrm{~m}$ of fine-grained material. \\
\hline GESS_MU & Glacial Environment and Surficial Sediments (GESS) geodatabase map unit attribute (table 1). \\
\hline Texture4 & 4-bin texture class (from table 3, with silty-clay and sandy-silt included as silty). \\
\hline Texture6 & 6-bin texture class (table 3 ). \\
\hline SiteUse & Monitoring or withdrawal well, or unknown. \\
\hline WellSource & Waterwell source: Quaternary sediment or bedrock. \\
\hline CrseStratSed & Log located in areas mapped as coarse stratified sediment (from GESS_MU and Texture6, table 2). \\
\hline Class_1A & Topographic setting of log in terrane $1 \mathrm{~A}$. \\
\hline Class_1G & Topographic setting of log in terrane $1 \mathrm{G}$. \\
\hline Stratified_1A & Log located in stratified drift aquifers mapped by Kontis and others (2004). \\
\hline FirstBedrock & Bedrock lithology at bedrock surface noted in lithologic log. \\
\hline \multicolumn{2}{|r|}{ Percentage of coarse material in Quaternary sediment } \\
\hline PercentCoarse & Penetrated by log. \\
\hline PercentCoarse7_5 & Upper $7.5 \mathrm{~m}$ \\
\hline PercentCoarse 15 & Upper $15 \mathrm{~m}$ \\
\hline PercentCoarse 30 & Upper $30 \mathrm{~m}$ \\
\hline \multicolumn{2}{|r|}{ Thickest aquifer-material interval } \\
\hline MainAquiferDepth & Depth. \\
\hline MainAquiferThick & Thickness. \\
\hline MainAquiferCL & Percentage of coarse material in sediment overlying aquifer-material interval. \\
\hline \multicolumn{2}{|r|}{ Deepest aquifer-material interval } \\
\hline BottomAquiferDepth & Depth. \\
\hline BottomAquiferThick & Thickness. \\
\hline BottomAquiferCL & Percentage of coarse material in sediment overlying aquifer-material interval. \\
\hline
\end{tabular}




\section{Summary}

The U.S. Geological Survey (USGS) has completed a study to assess the occurrence and characteristics of confined and unconfined glacial aquifers in the conterminous United States, their distribution and extent, and their potential intrinsic susceptibility and vulnerability. As part of that study, multiple hydrogeologic and geospatial datasets were organized into the hydrogeologic framework for the glacial aquifer system to three-dimensionally characterize the Quaternary sediments of the glaciated conterminous United States. These data were intended to aid in the identification and explanation of regional patterns in aquifer occurrence, productivity, and water quality in the glacial aquifer system. This report describes the components of the hydrogeologic framework: the Glacial Environments and Surficial Sediments (GESS) geodatabase, which includes lithologic, geomorphic, and stratigraphic characterization of surficial and glacial sediments; hydrogeologic terranes; public-supply and domestic well databases containing groundwater use information; and a geospatial framework for visualizing and interpreting available subsurface lithologic information derived from State-managed well records and geologic logs.

The GESS geodatabase - a geospatial framework that maps, categorizes, and characterizes the physical properties of the glacial sediments - was created from the Quaternary Atlas of the United States map series and the Map Database for Surficial Materials in the Conterminous United States geodatabases. The GESS geodatabase includes a map unit attribute (GESS_MU) with alluvial sediment, bedrock, colluvial sediment, eolian sediment, fill, ice-contact sediment, lacustrine sediment, marine sediment, organic sediment, outwash sediment, residual soil, solifluction sediment, till and water values; a geomorphic modifier attribute (GESS_Modifier) with "e" (end moraine), "g" (ground moraine), "s" (stagnation moraine), "d" (discontinuous or attenuated), and "f" (solifluction) values; attributes for stratified sediments and coarse-grained, stratified sediments (StratSed and CrseStratSed) to differentiate stratified, coarse-grained, stratified, and unstratified sediments; and a textural classification attribute (Texture6) with values of mostly sandy, sandy-silty, mostly silty, silty-clayey, mostly clayey, and mostly organic. Also included is a simplified bedrock geology dataset, an amalgamation of several Integrated Geologic Map Databases for the United States, for identification of potential areas of glacial aquifer and bedrock aquifer interaction. When interpreting or applying the GESS geodatabase attributes and values in a hydrogeologic context, several considerations must be made, such as the scale of the GESS geodatabase and the scale of the aquifer of interest, discontinuities in mapped features and lithological information at state and quadrangle map boundaries, and potential spatial discrepancies with spatial elements in the GESS geodatabase and other available geospatial datasets.

Hydrogeologic terranes were defined using four criteria: overall thickness of Quaternary sediments, the predominant modes of glacial deposition, the predominant texture of the surficial sediments, and the geologic age of the sediments. The first of those criteria was used to infer, delineate, and qualitatively rank hydrogeologic complexity that may exist in each terrane: lower complexity, moderate complexity, or higher complexity. Terranes of similar complexity were then evaluated based upon the remaining criteria: mode of deposition, texture, and geologic age; letter designations were appended to the numeric codes for complexity (for example, $1 \mathrm{~A}$ and $3 \mathrm{C}$ ) to denote differences. According to this classification methodology, the Quaternary sediments within the glaciated area of the conterminous United States were classified into 17 hydrogeologic terranes.

The compilation of groundwater-use information prepared for this study includes withdrawals from wells that derive water from surface-water infiltration, and the groundwater part delivered from combined systems that derive water from groundwater and surface-water sources. Records of public-supply groundwater usage were collected for parts of 24 States within the glaciated conterminous United States (excluding Kentucky) for water systems that withdraw groundwater through wells and springs. Two tables were prepared for the water-use data: a system-level table that lists information by system and a source-level table that lists information by well. The water-use records include identifiers for the U.S. Environmental Protection Agency and State agency databases, the ownership and type of public water system, the location and the population served by the system, withdrawal rates, well construction data, and the source aquifer of the water supply. Withdrawal data were obtained from the States' water-use registration, permitting, reporting, or allocation programs. Some withdrawal data were supplemented with information from the USGS Site-Specific Water-Use Data System (SWUDS) and by direct requests to State agencies or through various online resources, such as water-quality and water diversion reports. Per capita water-use values were obtained from the USGS Aggregate Water-Use Data System (AWUDS) database for 2010. Source aquifer, either Quaternary sediments or bedrock, were assigned for each public-water system based upon State-provided aquifer codes in their water-use reporting databases and well construction data if available, based on well depth in comparison to the available maps or spatial proximity to nearby adjacent well records with more complete data, or other methods. The public-water system records were checked to improve quality and completeness of inventories and associated data. The completed inventory represents the best estimates of public-supply groundwater withdrawals by source aquifer on the basis of the current state of scientific knowledge and data available.

A lithologic database for the glaciated conterminous United States was compiled from State well records, and lithologic logs consisting of 1,565,349 records in 24 States in the glaciated conterminous Unites States (excluding Kentucky), of which 740,727 are for wells that are for the purpose of withdrawing water. The well locations were intersected with the spatial datasets of the hydrogeologic terranes and from the GESS geodatabase. Attributes were added to the records for 
each well in the lithologic database describing the hydrogeologic terrane, the complexity of the hydrogeologic terrane, the surficial map unit, the texture of the surficial unit, the bedrock geology classification, and whether the unit was stratified and coarse. Characteristics of the Quaternary sediments penetrated by the wells were calculated from the lithologic data. The Quaternary sediment thickness was computed if the depth to bedrock was noted in the lithologic log. Several metrics that characterize the Quaternary sediments and potential aquifer materials penetrated by the wells were computed from the lithologic logs. Quaternary sediment was classified into finegrained (clay and silt) and coarse-grained (sand and gravel) categories. Aquifer material was considered to be 3 meters or more of contiguous coarse-grained material within a lithologic $\log$ with no more than 0.5 meter of intervening fine-grained material. The number of occurrences of aquifer-material intervals in each log was counted. The thickness, depth, thickness of the confining layer (if present), and the amount of fine-grained material within the aquifer-material interval were computed. Additional metrics were computed as to whether the aquifer-material interval was confined by at least 7.5, 15, or 30 meters of fine-grained material. Median values of each metric were aggregated using a 1-kilometer geospatial grid cell to deemphasize clusters in the data.

\section{Acknowledgments}

A special thanks to Sharon L. Qi, U.S. Geological Survey (USGS) physical scientist, for creating the original Quaternary atlas map geodatabase for the glaciated conterminous United States from existing quadrangle maps in the Quaternary Atlas of the United States map database series. The existence of the unified Quaternary atlas geodatabase helped guide this project in its earliest stages. In addition, a sincere thank you to Paul Heisig, USGS hydrologist, not only for his work on a modified geodatabase of the stratified-drift aquifers in the glaciated northeastern United States, but also for his consultation and advice when considering the surficial aquifers in glaciated mountainous regions. Compilation of the water-use data would not have been possible without the help of Leah Kammel, USGS hydrologist, the expertise of USGS water-use specialists throughout the study area, and the support of the USGS Groundwater Resources Program.

\section{References Cited}

Bayless, E.R., Arihood, L.D., Reeves, H.W., Sperl, B.J., Qi, S.L., Stipe, V.E., and Bunch, A.R., 2017, Maps of hydrogeologic information created from standardized water-well drillers' records of the glaciated United States: U.S. Geological Survey Scientific Investigations Report 2015-5105, 34 p. [Also available at https://doi.org/10.3133/ sir20155105.]
Booth, D.B., Troost, K.G., Clague, J.J., and Waitt, R.B., 2003, The Cordilleran ice sheet, in Gillespie, A.R., Porter, S.C., and Atwater, B.F., eds., The Quaternary period in the United States: Developments in Quaternary Sciences, v. 1, special issue, p. 17-43. [Also available at https://doi.org/10.1016/ S1571-0866(03)01002-9.]

Dewald, T., McKay, L., Bondelid, T., Johnston, C., Moore, R., and Rea, A., 2012, NHDPlus version 2-User guide: U.S. Environmental Protection Agency, 181 p., accessed November 15, 2014, at http://www.horizon-systems.com/NHDPlus/ NHDPlusV2_documentation.php.

Dicken, C.L., Nicholson, S.W., Horton, J.D., Kinney, S.A., Gunther, G., Foose, M.P., and Mueller, J.A.L., 2005, Preliminary integrated geologic map databases for the United States-Delaware, Maryland, New York, Pennsylvania, and Virginia: U.S. Geological Survey Open-File Report 20051325, [n.p.]. [Also available at https://pubs.er.usgs.gov/ publication/ofr20051325.]

Eberts, S.M., and George, L.L., 2000, Regional groundwater flow and geochemistry in the Midwestern Basin and Arches aquifer system in parts of Indiana, Ohio, Michigan and Illinois: U.S. Geological Survey Professional Paper 1423-C, 103 p. [Also available at https://pubs.er.usgs.gov/ publication/pp1423C.]

Ely, D.M., and Kahle, S.C., 2004, Conceptual model and numerical simulation of the ground-water-flow system in the unconsolidated deposits of the Colville River watershed, Stevens County, Washington: U.S. Geological Survey Scientific Investigations Report 2004-5237, 72 p. [Also available at https://pubs.er.usgs.gov/publication/sir20045237.]

Fullerton, D.S., Bush, C.A., and Pennell, J.N., 2003, Map of surficial deposits and materials in the eastern and central United States (east of $102^{\circ}$ west longitude): U.S. Geological Survey Geologic Investigations Series Map I-2789, scale 1:2,500,000. [Also available https://pubs.er.usgs.gov/ publication/i2789.]

Fullerton, D.S., and Richmond, G.M., comps., [variously dated], Quaternary geologic atlas of the United States: U.S. Geological Survey Miscellaneous Investigations Series Map I-1420, 33 quadrangles, scale 1:1,000,000. [Also available at https://on.doi.gov/2vwOIXJ.]

Garrity, C.P., and Soller, D.R., 2009, Database of the geologic map of North America; adapted from the map by J.C. Reed, Jr., and others (2005): U.S. Geological Survey Data Series 424, accessed November 28, 2017, at https://pubs.er.usgs.gov/publication/ds424.

Haj, A.E., Soller, D.R., Buchwald, C.A., Kauffman, L.J., Heisg, P.M., and Reddy, J., 2018, Databases used to develop a hydrogeologic framework for Quaternary sediments in the glaciated conterminous United States: U.S. Geological Survey data release, https://doi.org/10.5066/F71R6PQG. 
Jones, M.A., 1999, Geologic framework of the Puget Sound aquifer system, Washington and British Columbia: U.S. Geological Survey Professional Paper 1424-C, 31 p., 18 pls. [Also available at https://pubs.er.usgs.gov/ publication/pp1424C.]

Kontis, A.L., Randall, A.D., and Mazzaferro, D.L., 2004, Regional hydrology and simulation of flow of stratifieddrift aquifers in the glaciated northeastern United States: U.S. Geological Survey Professional Paper 1415-C, 156 p., 3 pls. [Also available at https://pubs.er.usgs.gov/publication/ pp1415C.]

Krulikas, R.K., and Koszalka, E.J., 1983, Geologic reconnaissance of an extensive clay unit in north-central Suffolk County, Long Island, New York: U.S. Geological Survey Water-Resources Investigations Report 82-4075, 13 p., $1 \mathrm{pl}$. [Also available at https://pubs.er.usgs.gov/publication/ wri824075.]

Leverett, F., and Sardeson, F.W., 1932, Quaternary geology of Minnesota and parts of adjacent States: U.S. Geological Survey Professional Paper 161, 149 p. [Also available at https://doi.org/10.3133/pp161.]

Ludington, S., Moring, B.C., Miller, R.J., Stone, P.A., Bookstrom, A.A., Bedford, D.R., Evans, J.G., Haxel, G.A., Nutt, C.J., Flynn, K.S., and Hopkins, M.J., 2007, Preliminary integrated geologic map databases for the United StatesWestern states - California, Nevada, Arizona, Washington, Oregon, Idaho, and Utah [version 1.3, December 2007]:

U.S. Geological Survey Open-File Report 2005-1305, 1.3, accessed November 28, 2017, at https://pubs.er.usgs.gov/ publication/ofr20051305.

Masterson, J.P., Stone, B.D., Walter, D.A., and Savoie, J.G., 1997, Hydrogeologic framework of western Cape Cod, Massachusetts: U.S. Geological Survey Hydrologic Atlas 741, scale 1:50,000. [Also available at https://pubs.er.usgs.gov/publication/ha741.]

Maupin, M.A., Kenny, J.F., Hutson, S.S., Lovelace, J.K., Barber, N.L., and Linsey, K.S., 2014, Estimated use of water in the United States in 2010: U.S. Geological Survey Circular 1405, 56 p., accessed November 28, 2017, at https://doi.org/10.3133/cir1405.

Mickelson, D.M., Clayton, L., Fullerton, D.S., and Borns, H.W., Jr., 1983, The Late Wisconsin glacial record of the Laurentide ice sheet in the United States, chap. 1 of Wright, H.E., Jr., ed., Late Quaternary environments of the United States: University of Minnesota Press, p. 3-37.
Nicholson, S.W., Dicken, C.L., Foose, M.P., and Mueller, J.A.L., 2007a, Integrated geologic map databases for the United States; the upper midwest states-Minnesota, Wisconsin, Michigan, Illinois, and Indiana [version 1.1; December 2007]: U.S. Geological Survey Open-File Report 2004-1355, accessed November 28, 2017, at https://pubs.er.usgs.gov/publication/ofr20041355.

Nicholson, S.W., Dicken, C.L., Horton, J.D., Foose, M.P., Mueller, J.A.L., and Hon, R., 2007b, Preliminary integrated geologic map databases for the United States-Connecticut, Maine, Massachusetts, New Hampshire, New Jersey, Rhode Island and Vermont [version 1.1; December 2007]: U.S. Geological Survey Open-File Report 2006-1272, accessed November 28, 2017, at https://pubs.er.usgs.gov/publication/ ofr20061272.

Nicholson, S.W., Dicken, C.L., Horton, J.D., Labay, K.A., Foose, M.P., and Mueller, J.A.L., 2007c, Preliminary integrated geologic map databases for the United StatesKentucky, Ohio, Tennessee, and West Virginia [version 1.1; December 2007]: U.S. Geological Survey Open-File Report 2005-1324, accessed November 28, 2017, at https://pubs.er.usgs.gov/publication/ofr20051324.

Oldale, R.N., and Barlow, R.A., 1986, Geologic map of Cape Cod and the Islands, Massachusetts: U.S. Geological Survey Miscellaneous Investigations Series Map I-1763, $1 \mathrm{pl}$. [Also available at https://pubs.er.usgs.gov/publication/ i1763.]

Rowe, G.L., Gilliom, R.J., and Woodside, M.D., 2013, Tracking and forecasting the nation's water qualityPriorities and strategies for 2013-2023: U.S. Geological Survey Fact Sheet 2013-3008, 6 p. [Also available at https://pubs.er.usgs.gov/publication/fs20133008.]

Smolensky, D.A., Buxton, H.T., and Shernoff, P.K., 1989, Hydrologic framework of Long Island, New York: U.S. Geological Survey Hydrologic Investigations Atlas HA-709, 3 sheets, scale 1:250,000. [Also available at https://pubs.er.usgs.gov/publication/ha709.]

Soller, D.R., 1993, Map showing the thickness and character of Quaternary sediments in the glaciated United States east of the Rocky Mountains-Northeastern states, the Great Lakes, and parts of southern Ontario and the Atlantic offshore area (east of 80 degrees 31 minutes): U.S. Geological Survey Miscellaneous Investigations Series Map I-1970-A, scale 1:1,000,000. [Also available at https://ngmdb.usgs.gov/Prodesc/proddesc_10047.htm.] 
Soller, D.R., 1994, Map showing the thickness and character of Quaternary sediments in the glaciated United States east of the Rocky Mountains-Northeastern plains states (west of 102 degrees west longitude): U.S. Geological Survey Miscellaneous Investigations Series Map I-1970-D, scale 1:1,000,000. [Also available at https://ngmdb.usgs.gov/Prodesc/proddesc_10048.htm.]

Soller, D.R., 1997, Map showing the thickness and character of Quaternary sediments in the glaciated United States, east of the Rocky Mountains-Northern and central plains states (90 degrees to 102 degrees west longitude): U.S. Geological Survey Miscellaneous Investigations Series Map I-1970-C, scale 1:1,000,000. [Also available at https://ngmdb.usgs.gov/Prodesc/proddesc_13020.htm.]

Soller, D.R., 1998, Map showing the thickness and character of Quaternary sediments in the glaciated United States east of the Rocky Mountains-Northern Great Lakes states and central Mississippi Valley states, the Great Lakes, and southern Ontario (80 degrees 31' to 93 degrees west longitude): U.S. Geological Survey Miscellaneous Investigations Series Map I-1970-B, scale 1:1,000,000. [Also available at https://ngmdb.usgs.gov/Prodesc/proddesc_13019.htm.]

Soller, D.R., and Garrity, C.P., 2018, Quaternary sediment thickness and bedrock topography of the glaciated United States east of the Rocky Mountains: U.S. Geological Survey Scientific Investigations Map 3392, 2 sheets, scale 1:5,000,000. [Also available at https://doi.org/10.3133/ $\operatorname{sim} 3392$.

Soller, D.R., Packard, P.H., and Garrity, C.P., 2012, Database for USGS Map I-1970-Map showing the thickness and character of Quaternary sediments in the glaciated United States east of the Rocky Mountains: U.S. Geological Survey Data Series 656, scale 1:1,000,000, accessed November 28, 2017, at https://pubs.er.usgs.gov/publication/ds656.

Soller, D.R., Reheis, M.C., Garrity, C.P., and Van Sistine, D.R., 2009, Map database for surficial materials in the conterminous United States: U.S. Geological Survey Data Series 425, scale 1:5,000,000, accessed November 28, 2017, at https://pubs.er.usgs.gov/publication/ds425.

Stoeser, D.B., Green, G.N., Morath, L.C., Heran, W.D., Wilson, A.B., Moore, D.W., and Van Gosen, B.S., 2007, Preliminary integrated geologic map databases for the United States - Central states-Montana, Wyoming, Colorado, New Mexico, North Dakota, South Dakota, Nebraska, Kansas, Oklahoma, Texas, Iowa, Missouri, Arkansas, and Louisiana [version 1.2; December 2007]: U.S. Geological Survey Open-File Report 2005-1351, accessed November 28, 2017, at https://pubs.er.usgs.gov/publication/ ofr20051351.
U.S. Environmental Protection Agency, 2013, Safe drinking water information system (SDWIS): U.S. Environmental Protection Agency database, accessed November 28, 2017, at https://www3.epa.gov/enviro/facts/sdwis/search.html.

U.S. Geological Survey, 1997, User's manual for the national water information system (NWIS); chapter 5, Water-use data system; part 1, Site-specific water-use data system (SWUDS) [version 1.2; 1997]: U.S. Geological Survey Open-File Report 97-636, accessed November 4, 2016, at https://pubs.er.usgs.gov/publication/ofr97636.

U. S. Geological Survey, 1998, National water information system (NWIS): U.S. Geological Survey Fact Sheet 1998-027, 2 p., accessed August 1, 2017, at https://pubs.er.usgs.gov/publication/fs02798.

U.S. Geological Survey, 2015, USGS water data for the nation: U.S. Geological Survey National Water Information System database, accessed August 13, 2015, at https://doi.org/10.5066/F7P55KJN.

Vickers, A., 2001, Water use and conservation-Homes, landscapes, businesses, industries, farms: Amherst, Mass., Waterplow Press, 446 p.

Walter, D.A., and Whealan, A.T., 2005, Simulated water sources and effects of pumping on surface and ground water, Sagamore and Monomoy flow lenses, Cape Cod, Massachusetts: U.S. Geological Survey Scientific Investigations Report 2004-5181, 85 p.

Yager, R.M., Kauffman, L.J., Buchwald, C.A., Westenbroek, S.M., and Reddy, J.E., 2018a, Digital products from a hydrogeologic framework for Quaternary sediments within the glaciated conterminous United States: U.S. Geological Survey data release, https://doi.org/10.5066/F7HH6J8X.

Yager, R.M., Kauffman, L.J., Soller, D.R., Haj, A.E., Heisig, P.M., Buchwald, C.A., Westenbroek, S.M., and Reddy, J.E., 2018b, Characterization and occurrence of confined and unconfined aquifers in Quaternary sediments in the glaciated conterminous United States: U.S. Geological Survey Scientific Investigations Report 2018-5091, 90 p., https://doi.org/10.3133/sir20185091. 

Table 4 
Table 4. Groundwater usage for public-supply water systems, by State, in the glaciated conterminous United States.

[A public water-supply (PWS) system is a system for the provision to the public of piped water for human consumption that has at least 15 service connections, or regularly serves an average of at least 25 individuals daily at least 60 days out of the year. Usage has been divided into community and noncommunity water systems. Summarized water-use data are from 2009 to 2013. —, no value determined]

\begin{tabular}{|c|c|c|c|}
\hline Public water system type or aquifer source & Total systems & $\begin{array}{c}\text { Community } \\
\text { water systems }{ }^{1}\end{array}$ & $\begin{array}{l}\text { Noncommunity } \\
\text { water systems }{ }^{1}\end{array}$ \\
\hline \multicolumn{4}{|c|}{ Glaciated conterminous United States (all or parts of 24 States) } \\
\hline Water systems & 71,566 & 14,097 & 57,469 \\
\hline Population served, in thousands & 42,198 & 34,839 & 7,360 \\
\hline Groundwater usage, in million cubic meters per year & 5,527 & 5,271 & 255 \\
\hline \multicolumn{4}{|l|}{ Usage by aquifer source, in million cubic meters per year: } \\
\hline Quaternary sediment ${ }^{3}$ & 2,697 & 2,611 & 86.2 \\
\hline Bedrock $^{4}$ & 1,666 & 1,551 & 116 \\
\hline Mixed $^{5}$ & 1,033 & 1,015 & 18.7 \\
\hline Unknown $^{6}$ & 130.1 & 95.4 & 34.7 \\
\hline \multicolumn{4}{|c|}{ Connecticut (100 percent of counties) } \\
\hline Water systems & 2,375 & 481 & 1,894 \\
\hline Population served, in thousands & 1,218 & 1,055 & 163 \\
\hline Groundwater usage, in million cubic meters per year & 213 & 204 & 8.58 \\
\hline \multicolumn{4}{|l|}{ Usage by aquifer source, in million cubic meters per year: } \\
\hline Quaternary sediment ${ }^{3}$ & 12.7 & 12.6 & 0.0886 \\
\hline Bedrock $^{4}$ & 114 & 106 & 8.49 \\
\hline Mixed $^{5}$ & 85.6 & 85.6 & - \\
\hline Unknown $^{6}$ & - & - & - \\
\hline \multicolumn{4}{|c|}{ Idaho (2.5 percent of counties) } \\
\hline Water systems & 99 & 35 & 64 \\
\hline Population served, in thousands & 14.7 & 10.8 & 3.96 \\
\hline Groundwater usage, in million cubic meters per year & 3.14 & 3.02 & 0.116 \\
\hline \multicolumn{4}{|l|}{ Usage by aquifer source, in million cubic meters per year: } \\
\hline Quaternary sediment ${ }^{3}$ & 3.14 & 3.02 & 0.112 \\
\hline Bedrock $^{4}$ & - & - & - \\
\hline Mixed $^{5}$ & 0.00415 & - & 0.00415 \\
\hline Unknown $^{6}$ & - & - & - \\
\hline \multicolumn{4}{|c|}{ Illinois (93.8 percent of counties) } \\
\hline Water systems & 3,407 & 1,227 & 2,180 \\
\hline Population served, in thousands & 4,426 & 4,080 & 346 \\
\hline Groundwater usage, in million cubic meters per year & 519 & 507 & 12.0 \\
\hline \multicolumn{4}{|l|}{ Usage by aquifer source, in million cubic meters per year: } \\
\hline Quaternary sediment ${ }^{3}$ & 220 & 218 & 2.44 \\
\hline Bedrock $^{4}$ & 159 & 157 & 2.64 \\
\hline Mixed $^{5}$ & 133 & 133 & - \\
\hline Unknown $^{6}$ & 6.96 & 0.0644 & 6.90 \\
\hline \multicolumn{4}{|c|}{ Indiana (84.3 percent of counties) } \\
\hline Water systems & 3,442 & 628 & 2,814 \\
\hline Population served, in thousands & 3,402 & 2,897 & 506 \\
\hline Groundwater usage, in million cubic meters per year & 469 & 450 & 19.3 \\
\hline \multicolumn{4}{|l|}{ Usage by aquifer source, in million cubic meters per year: } \\
\hline Quaternary sediment ${ }^{3}$ & 342 & 335 & 6.73 \\
\hline Bedrock $^{4}$ & 25.1 & 23.3 & 1.84 \\
\hline Mixed $^{5}$ & 87.2 & 87.2 & - \\
\hline Unknown $^{6}$ & 15.1 & 4.42 & 10.7 \\
\hline
\end{tabular}


Table 4. Groundwater usage for public-supply water systems, by State, in the glaciated conterminous United States. -Continued

[A public water-supply (PWS) system is a system for the provision to the public of piped water for human consumption that has at least 15 service connections, or regularly serves an average of at least 25 individuals daily at least 60 days out of the year. Usage has been divided into community and noncommunity water systems. Summarized water-use data are from 2009 to 2013 . —, no value determined]

\begin{tabular}{|c|c|c|c|}
\hline Public water system type or aquifer source & Total systems & $\begin{array}{c}\text { Community } \\
\text { water systems }\end{array}$ & $\begin{array}{l}\text { Noncommunity } \\
\text { water systems }{ }^{1}\end{array}$ \\
\hline \multicolumn{4}{|c|}{ lowa (100 percent of counties) } \\
\hline Water systems & 1,743 & 981 & 762 \\
\hline Population served, in thousands & 2,274 & 2,151 & 123 \\
\hline Groundwater usage, in million cubic meters per year & 416 & 412 & 4.95 \\
\hline \multicolumn{4}{|l|}{ Usage by aquifer source, in million cubic meters per year: } \\
\hline Quaternary sediment ${ }^{3}$ & 232 & 231 & 1.02 \\
\hline Bedrock $^{4}$ & 162 & 159 & 3.58 \\
\hline Mixed $^{5}$ & 21.8 & 21.7 & 0.0167 \\
\hline Unknown $^{6}$ & 0.336 & 0.00400 & 0.332 \\
\hline \multicolumn{4}{|c|}{ Kansas (8.3 percent of counties) } \\
\hline Water systems & 131 & 129 & 2 \\
\hline Population served, in thousands & 442 & 442 & 0.150 \\
\hline Groundwater usage, in million cubic meters per year & 64.3 & 64.3 & 0.009 \\
\hline \multicolumn{4}{|l|}{ Usage by aquifer source, in million cubic meters per year: } \\
\hline Quaternary sediment ${ }^{3}$ & 64.3 & 64.3 & 0.00915 \\
\hline Bedrock $^{4}$ & - & - & - \\
\hline Mixed $^{5}$ & - & - & - \\
\hline Unknown $^{6}$ & - & - & - \\
\hline \multicolumn{4}{|c|}{ Maine (100 percent of counties) } \\
\hline Water systems & 1,420 & 301 & 1,119 \\
\hline Population served, in thousands & 406 & 207 & 199 \\
\hline Groundwater usage, in million cubic meters per year & 41.3 & 34.6 & 6.72 \\
\hline \multicolumn{4}{|l|}{ Usage by aquifer source, in million cubic meters per year: } \\
\hline Quaternary sediment ${ }^{3}$ & 29.2 & 29.0 & 0.237 \\
\hline Bedrock $^{4}$ & 10.1 & 4.41 & 5.71 \\
\hline Mixed $^{5}$ & 1.15 & 1.15 & - \\
\hline Unknown $^{6}$ & 0.773 & 0.00625 & 0.767 \\
\hline \multicolumn{4}{|c|}{ Massachusetts (100 percent of counties) } \\
\hline Water systems & 1,448 & 331 & 1,117 \\
\hline Population served, in thousands & 1,802 & 1,587 & 214 \\
\hline Groundwater usage, in million cubic meters per year & 182 & 176 & 6.49 \\
\hline \multicolumn{4}{|l|}{ Usage by aquifer source, in million cubic meters per year: } \\
\hline Quaternary sediment ${ }^{3}$ & 169 & 167 & 2.491 \\
\hline Bedrock $^{4}$ & 7.52 & 3.84 & 3.69 \\
\hline Mixed $^{5}$ & 5.03 & 5.03 & - \\
\hline Unknown $^{6}$ & 0.770 & 0.453 & 0.317 \\
\hline \multicolumn{4}{|c|}{ Michigan (100 percent of counties) } \\
\hline Water systems & 15,076 & 1,081 & 13,995 \\
\hline Population served, in thousands & 2,998 & 1,619 & 1,380 \\
\hline Groundwater usage, in million cubic meters per year & 320 & 276 & 44.0 \\
\hline \multicolumn{4}{|l|}{ Usage by aquifer source, in million cubic meters per year: } \\
\hline Quaternary sediment ${ }^{3}$ & 191 & 169 & 22.5 \\
\hline Bedrock $^{4}$ & 108 & 91.4 & 16.6 \\
\hline Mixed $^{5}$ & 17.5 & 15.4 & 2.11 \\
\hline Unknown $^{6}$ & 3.40 & 0.608 & 2.79 \\
\hline
\end{tabular}


Table 4. Groundwater usage for public-supply water systems, by State, in the glaciated conterminous United States. -Continued

[A public water-supply (PWS) system is a system for the provision to the public of piped water for human consumption that has at least 15 service connections, or regularly serves an average of at least 25 individuals daily at least 60 days out of the year. Usage has been divided into community and noncommunity water systems. Summarized water-use data are from 2009 to 2013 . —, no value determined]

\begin{tabular}{|c|c|c|c|}
\hline Public water system type or aquifer source & Total systems & $\begin{array}{c}\text { Community } \\
\text { water systems }{ }^{1}\end{array}$ & $\begin{array}{l}\text { Noncommunity } \\
\text { water systems }\end{array}$ \\
\hline \multicolumn{4}{|c|}{ Minnesota (100 percent of counties) } \\
\hline Water systems & 6,781 & 904 & 5,877 \\
\hline Population served, in thousands & 3,763 & 3,163 & 601 \\
\hline Groundwater usage, in million cubic meters per year & 543 & 527 & 16.4 \\
\hline \multicolumn{4}{|l|}{ Usage by aquifer source, in million cubic meters per year: } \\
\hline Quaternary sediment ${ }^{3}$ & 126 & 119 & 6.73 \\
\hline Bedrock $^{4}$ & 317 & 314 & 3.18 \\
\hline Mixed $^{5}$ & 92.8 & 92.7 & 0.106 \\
\hline Unknown $^{6}$ & 7.55 & 1.15 & 6.41 \\
\hline \multicolumn{4}{|c|}{ Missouri (36.5 percent of counties) } \\
\hline Water systems & 296 & 257 & 39 \\
\hline Population served, in thousands & 864 & 852 & 12.3 \\
\hline Groundwater usage, in million cubic meters per year & 146 & 144 & 1.80 \\
\hline \multicolumn{4}{|l|}{ Usage by aquifer source, in million cubic meters per year: } \\
\hline Quaternary sediment ${ }^{3}$ & 7.53 & 7.53 & - \\
\hline Bedrock $^{4}$ & 124 & 123 & 1.77 \\
\hline Mixed $^{5}$ & 12.3 & 12.3 & - \\
\hline Unknown $^{6}$ & 1.67 & 1.64 & 0.0276 \\
\hline \multicolumn{4}{|c|}{ Montana (34.6 percent of counties) } \\
\hline Water systems & 544 & 198 & 346 \\
\hline Population served, in thousands & 145 & 96.4 & 48.6 \\
\hline Groundwater usage, in million cubic meters per year & 20.5 & 18.9 & 1.62 \\
\hline \multicolumn{4}{|l|}{ Usage by aquifer source, in million cubic meters per year: } \\
\hline Quaternary sediment ${ }^{3}$ & 14.8 & 14.1 & 0.620 \\
\hline Bedrock $^{4}$ & 5.77 & 4.77 & 0.999 \\
\hline $\operatorname{Mixed}^{5}$ & - & - & - \\
\hline Unknown $^{6}$ & - & - & - \\
\hline Water systems & 583 & 313 & 270 \\
\hline \multicolumn{4}{|c|}{ Nebraska (21.6 percent of counties) } \\
\hline Population served, in thousands & 705 & 663 & 41.7 \\
\hline Groundwater usage, in million cubic meters per year & 166 & 164 & 2.26 \\
\hline \multicolumn{4}{|l|}{ Usage by aquifer source, in million cubic meters per year: } \\
\hline Quaternary sediment ${ }^{3}$ & 49.6 & 48.8 & 0.803 \\
\hline Bedrock $^{4}$ & 4.59 & 4.17 & 0.421 \\
\hline Mixed $^{5}$ & 112 & 111 & 1.03 \\
\hline Unknown $^{6}$ & - & - & - \\
\hline \multicolumn{4}{|c|}{ New Hampshire (100 percent of counties) } \\
\hline Water systems & 2,217 & 645 & 1,572 \\
\hline Population served, in thousands & 774 & 478 & 297 \\
\hline Groundwater usage, in million cubic meters per year & 64.5 & 53.3 & 11.3 \\
\hline \multicolumn{4}{|l|}{ Usage by aquifer source, in million cubic meters per year: } \\
\hline Quaternary sediment ${ }^{3}$ & 4.62 & 4.10 & 0.512 \\
\hline Bedrock $^{4}$ & 58.5 & 47.7 & 10.8 \\
\hline Mixed $^{5}$ & 1.41 & 1.41 & - \\
\hline Unknown $^{6}$ & - & - & - \\
\hline
\end{tabular}


Table 4. Groundwater usage for public-supply water systems, by State, in the glaciated conterminous United States. -Continued

[A public water-supply (PWS) system is a system for the provision to the public of piped water for human consumption that has at least 15 service connections, or regularly serves an average of at least 25 individuals daily at least 60 days out of the year. Usage has been divided into community and noncommunity water systems. Summarized water-use data are from 2009 to 2013 . —, no value determined]

\begin{tabular}{|c|c|c|c|}
\hline Public water system type or aquifer source & Total systems & $\begin{array}{c}\text { Community } \\
\text { water systems }{ }^{1}\end{array}$ & $\begin{array}{l}\text { Noncommunity } \\
\text { water systems }^{1}\end{array}$ \\
\hline \multicolumn{4}{|c|}{ New Jersey (33.2 percent of counties) } \\
\hline Water systems & 1,214 & 191 & 1,023 \\
\hline Population served, in thousands & 1,489 & 1,231 & 259 \\
\hline Groundwater usage, in million cubic meters per year & 213 & 200.4 & 12.3 \\
\hline \multicolumn{4}{|l|}{ Usage by aquifer source, in million cubic meters per year: } \\
\hline Quaternary sediment ${ }^{3}$ & 20.9 & 18.8 & 2.11 \\
\hline Bedrock $^{4}$ & 107.8 & 97.6 & 10.2 \\
\hline Mixed $^{5}$ & 68.0 & 68.0 & - \\
\hline Unknown $^{6}$ & 16.0 & 16.0 & - \\
\hline \multicolumn{4}{|c|}{ New York (98 percent of counties) } \\
\hline Water systems & 7,494 & 1,639 & 5,855 \\
\hline Population served, in thousands & 4,474 & 3,659 & 815 \\
\hline Groundwater usage, in million cubic meters per year & 607 & 580 & 27.2 \\
\hline \multicolumn{4}{|l|}{ Usage by aquifer source, in million cubic meters per year: } \\
\hline Quaternary sediment ${ }^{3}$ & 147 & 128 & 19.3 \\
\hline Bedrock $^{4}$ & ${ }^{7} 100$ & ${ }^{7} 100$ & 0.01 \\
\hline Mixed $^{5}$ & 299 & 291 & 7.90 \\
\hline Unknown $^{6}$ & 61.3 & 61.3 & - \\
\hline \multicolumn{4}{|c|}{ North Dakota (85.1 percent of counties) } \\
\hline Water systems & 345 & 211 & 134 \\
\hline Population served, in thousands & 299 & 285 & 13.6 \\
\hline Groundwater usage, in million cubic meters per year & 47.8 & 47.3 & 0.486 \\
\hline \multicolumn{4}{|l|}{ Usage by aquifer source, in million cubic meters per year: } \\
\hline Quaternary sediment ${ }^{3}$ & 44.3 & 44.1 & 0.202 \\
\hline Bedrock $^{4}$ & 2.78 & 2.60 & 0.180 \\
\hline Mixed $^{5}$ & 0.0555 & 0.0555 & - \\
\hline Unknown $^{6}$ & 0.734 & 0.629 & 0.104 \\
\hline \multicolumn{4}{|c|}{ Ohio (71.8 percent of counties) } \\
\hline Water systems & 3,911 & 812 & 3,099 \\
\hline Population served, in thousands & 5,119 & 4,588 & 531 \\
\hline Groundwater usage, in million cubic meters per year & 573 & 552 & 20.4 \\
\hline \multicolumn{4}{|l|}{ Usage by aquifer source, in million cubic meters per year: } \\
\hline Quaternary sediment ${ }^{3}$ & 495 & 491 & 4.04 \\
\hline Bedrock $^{4}$ & 48.7 & 42.6 & 6.08 \\
\hline Mixed $^{5}$ & 23.7 & 16.9 & 6.85 \\
\hline Unknown $^{6}$ & 5.31 & 1.90 & 3.42 \\
\hline \multicolumn{4}{|c|}{ Pennsylvania (31.7 percent of counties) } \\
\hline Water systems & 3,604 & 665 & 2,939 \\
\hline Population served, in thousands & 970 & 484 & 486 \\
\hline Groundwater usage, in million cubic meters per year & 82.2 & 63.6 & 18.6 \\
\hline \multicolumn{4}{|l|}{ Usage by aquifer source, in million cubic meters per year: } \\
\hline Quaternary sediment ${ }^{3}$ & 19.6 & 19.5 & 0.0387 \\
\hline Bedrock $^{4}$ & 49.4 & 33.4 & 16.0 \\
\hline Mixed $^{5}$ & 3.89 & 3.89 & - \\
\hline Unknown $^{6}$ & 9.4 & 6.77 & 2.60 \\
\hline
\end{tabular}


Table 4. Groundwater usage for public-supply water systems, by State, in the glaciated conterminous United States. -Continued

[A public water-supply (PWS) system is a system for the provision to the public of piped water for human consumption that has at least 15 service connections, or regularly serves an average of at least 25 individuals daily at least 60 days out of the year. Usage has been divided into community and noncommunity water systems. Summarized water-use data are from 2009 to 2013. _, no value determined]

\begin{tabular}{|c|c|c|c|}
\hline Public water system type or aquifer source & Total systems & $\begin{array}{c}\text { Community } \\
\text { water systems }{ }^{1}\end{array}$ & $\begin{array}{l}\text { Noncommunity } \\
\text { water systems }{ }^{1}\end{array}$ \\
\hline \multicolumn{4}{|c|}{ Rhode Island (100 percent of counties) } \\
\hline Water systems & 441 & 64 & 377 \\
\hline Population served, in thousands & 336 & 256 & 79.5 \\
\hline Groundwater usage, in million cubic meters per year & 37.4 & 34.4 & 2.96 \\
\hline \multicolumn{4}{|l|}{ Usage by aquifer source, in million cubic meters per year: } \\
\hline Quaternary sediment ${ }^{3}$ & 30.9 & 30.6 & 0.330 \\
\hline Bedrock $^{4}$ & 6.29 & 3.80 & 2.49 \\
\hline Mixed $^{5}$ & 0.194 & 0.0520 & 0.142 \\
\hline Unknown $^{6}$ & 0.0371 & 0.0341 & 0.00298 \\
\hline \multicolumn{4}{|c|}{ South Dakota (51.1 percent of counties) } \\
\hline Water systems & 165 & 152 & 13 \\
\hline Population served, in thousands & 423 & 419 & 3.52 \\
\hline Groundwater usage, in million cubic meters per year & 93.6 & 93.5 & 0.083 \\
\hline \multicolumn{4}{|l|}{ Usage by aquifer source, in million cubic meters per year: } \\
\hline Quaternary sediment ${ }^{3}$ & 83.5 & 83.4 & 0.0656 \\
\hline Bedrock $^{4}$ & 9.14 & 9.12 & 0.0178 \\
\hline Mixed $^{5}$ & 0.942 & 0.942 & - \\
\hline Unknown $^{6}$ & 0.0151 & 0.0151 & - \\
\hline \multicolumn{4}{|c|}{ Vermont (100 percent of counties) } \\
\hline Water systems & 1,097 & 308 & 789 \\
\hline Population served, in thousands & 295 & 174 & 121 \\
\hline Groundwater usage, in million cubic meters per year & 24.0 & 19.7 & 4.34 \\
\hline \multicolumn{4}{|l|}{ Usage by aquifer source, in million cubic meters per year: } \\
\hline Quaternary sediment ${ }^{3}$ & 9.72 & 7.87 & 1.85 \\
\hline Bedrock $^{4}$ & 14.3 & 11.8 & 2.49 \\
\hline Mixed $^{5}$ & - & - & - \\
\hline Unknown $^{6}$ & - & - & - \\
\hline \multicolumn{4}{|c|}{ Washington (48.7 percent of counties) } \\
\hline Water systems & 2,230 & 1,434 & 796 \\
\hline Population served, in thousands & 2,312 & 2,136 & 176 \\
\hline Groundwater usage, in million cubic meters per year & 271 & 266 & 5.79 \\
\hline \multicolumn{4}{|l|}{ Usage by aquifer source, in million cubic meters per year: } \\
\hline Quaternary sediment ${ }^{3}$ & 268 & 262 & 5.79 \\
\hline Bedrock $^{4}$ & 0.213 & 0.213 & - \\
\hline Mixed $^{5}$ & 3.33 & 3.33 & - \\
\hline Unknown ${ }^{6}$ & 0.281 & 0.281 & - \\
\hline
\end{tabular}


Table 4. Groundwater usage for public-supply water systems, by State, in the glaciated conterminous United States. -Continued

[A public water-supply (PWS) system is a system for the provision to the public of piped water for human consumption that has at least 15 service connections, or regularly serves an average of at least 25 individuals daily at least 60 days out of the year. Usage has been divided into community and noncommunity water systems. Summarized water-use data are from 2009 to 2013 . —, no value determined]

\begin{tabular}{lccc}
\hline \multicolumn{1}{c}{ Public water system type or aquifer source } & Total systems & $\begin{array}{c}\text { Community } \\
\text { water systems }\end{array}$ & $\begin{array}{c}\text { Noncommunity } \\
\text { water systems }^{\mathbf{1}}\end{array}$ \\
\hline \multicolumn{1}{c}{ Wisconsin (100 percent of counties) } & & \\
\hline Water systems & 11,503 & 1,110 & 10,393 \\
Population served, in thousands & 3,248 & 2,308 & 940 \\
Groundwater usage, in million cubic meters per year & 409 & 381 & 27.8 \\
Usage by aquifer source, in million cubic meters per year: & & \\
Quaternary sediment & & \\
Bedrock $^{4}$ & 112 & 104 & 8.15 \\
Mixed $^{5}$ & 231 & 212 & 18.8 \\
Unknown $^{6}$ & 65.2 & 64.7 & 0.505 \\
\hline
\end{tabular}

${ }^{1}$ Community water system is a PWS that serves at least 15 service connections used by year-round residents or regularly serves at least 25 year-round residents. Examples are cities, rural water districts, correctional facilities, and mobile home parks.

${ }^{2}$ Noncommunity water system is a PWS that is not a community water system. There are two types: Nontransient, noncommunity water systems regularly serve at least 25 of the same persons over 6 months per year. Examples include day care facilities, factories, schools, and office buildings. Transient, noncommunity water systems provide water in a place where people do not remain for long periods of time. Potable use is for more than 25 persons at least 60 days of the year. Examples include hotels, restaurants, retail stores, and churches.

${ }^{3}$ Quaternary sediments include materials of glacial, postglacial, and nonglacial origin.

${ }^{4}$ Bedrock is composed of consolidated material such as sedimentary, carbonate, metamorphic, plutonic, or volcanic rock. Cretaceous sediments for Long Island, New York, were assigned to this aquifer source.

${ }^{5}$ Mixed is an aquifer that includes both Quaternary sediments and bedrock aquifers.

${ }^{6}$ Indicates that the aquifer could not be determined.

${ }^{7}$ Total includes 71 million cubic meters per year from bedrock aquifers in upstate New York and 29 million cubic meters per year from Cretaceous sediments on Long Island. 

For additional information about this publication, contact:

Director, USGS Central Midwest Water Science Center

U.S. Geological Survey

400 South Clinton Street

Iowa City, IA 52240

or visit https://www.usgs.gov/centers/cm-water

Publishing support provided by the

Madison, Pembroke, and Rolla Publishing Service Centers 


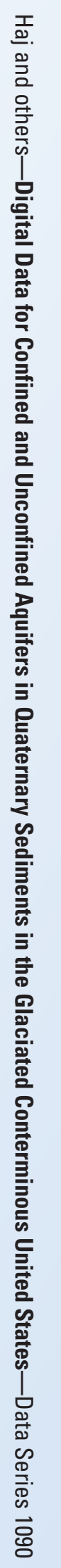

